\title{
Gifititariograrifea
}

Crítica Historiográfica. Natal, v.1, n.2, nov./dez. 2021 | 2764-2666

Publicação: 2021-12-30

\section{Corpo editorial}

\section{Editor-chefe}

- Profa. Dra. Margarida Maria Dias de Oliveira (UFRN)

- Universidade Federal do Rio Grande do Norte, UFRN-Campus Central, BR 101, Lagoa nova. CEP 59078-970, Natal-RN. Cel.: 84991641675 E-mail margaridahistoria@yahoo.com.br

\section{Autores corporativos}

- Grupo de pesquisa "Espaços, poder, práticas sociais" da Universidade Federal do Rio Grande do Norte. Campus Universitário Lagoa Nova | Caixa Postal 1524 | CEP 59078-900 | Natal/RN - Brasil

- CNPq: http://dgp.cnpq.br/dgp/espelhogrupo/595907.

- E-mail: eppsgrupo@gmail.com

- Facebook Espaços, Poder e Práticas Sociais

- Instagram: @eppsgrupo

- Youtube: https://www.youtube.com/channel/UCNB9v2gy5CCHwstVdNdg-A

- Grupo de pesquisa "Aprendizagem histórica em espaços escolares e não escolares". Cidade Universitária Prof. José Aloísio de Campos. Bloco Departamental I, sala 9, Av. Marechal Rondon, S/N - Rosa Elze, 49100000 São Cristóvão - SE

- CNPq: dgp.cnpq.br/dgp/espelhogrupo/3087460812169010.

\section{Editor-executivo}

- Prof. Dr. Itamar Freitas (UFS)

\section{Vice editores}

- Prof. Dr. Magno Francisco de Jesus Santos (UFRN)

- Prof. Dr. Fábio Alves dos Santos (UFS)

\section{Comissão editorial}

- Prof. Dr. Almir Félix Batista de Oliveira (UFRN)

- Prof. Dr. André Cabral Honor (UnB)

- Prof. Dr. Arnaldo Martin Szlachta Junior (UFPE)

- Prof. Dr. Bruno Balbino Aires da Costa (IFRN)

- Profa. Dra. Carmem Zeli Gil (UFRGS)1 
- Prof. Dr. Dilton Cândido Maynard (UFRJ/UFS)

- Prof. Dr. Eduardo Henrique Barbosas de Vasconcelos (UEG)

- Prof. Dr. Erinaldo Vicente Cavalcanti (UNIFESPA)

- Profa. Dra. Fabíula Sevilha de Souza (UFRN)

- Prof. Dr. Francisco Egberto de Melo (URCA)

- Profa. Dra. Flavia Eloisa Caimi (UPF)

- Prof. Dr. Hermeson Alves de Menezes (UAB/UFS)

- Profa. Dra. Jane Derarovele Semeão (URCA)

- Prof. Dr. João Mauricio Gomes Ribeiro (UNIR)

- Profa. Dra. Joceneide Santos Cunha (UNEB)

- Prof. Dr. José Vieira da Cruz (UFS)

- Profa. Dra. Juliana Teixeira Souza (UFRN)

- Prof. Dr. Jucieldo Ferreira Alexandre (UFCA)

- Prof. Dr. Lucas Pinheiro (UFS)

- Prof. Dr. Lucas Victor Silva (UFRPE)

- Dra. Maria Augusta Castilho (UCDB)

- Profa. Dra. Maria de Lourdes Mônaco Janotti (USP)

- Profa. Dra. Maria Fernanda Batista Bicalho (UFF)

- Profa. Dra. Marieta de Moraes Ferreira (UFRJ)

- Profa. Dra. Marta Margarida Andrade Lima (UFRPE)

- Prof. Dr. Mauro Cézar Coelho (UFPA)

- Dra. Mônica Martins da Silva (UFSC)

- Prof. Dr. Péricles Andrade (UFS)

- Prof. Dr. Renilson Rosa Ribeiro (UFMT)

- Prof. Dr. Robson Wiliam Potier (SEEC/RN)

- Profa. Dra. Rosa Maria Godoy Silveira (UFPB)

- Profa. Dra. Rosiane da Silva Ribeiro Bechler (UFVJM)

- Profa. Dra. Sandra Regina Ferreira Oliveira (UEL/PR)

- Profa. Dra. Sonia Menezes (URCA)

- Prof. Dr. Tiago Santos Almeida (UFGO)

- Profa. Dra. Vanessa Spinosa (UFRN)

- Prof. Dr. Wesley Garcia Ribeiro Silva (UFPA)

- Profa. Dra. Wilma de Nazaré Baia Coelho (UFPA)

\section{Apoio técnico}

- Antonio Marcos Pinto Coelho (PlanPlen Web Marketing)

- Maria Luiza Dantas Lins (UFRN)

- Rebeca Nadine de Araújo Paiva (UFRN) 


\section{ctiter \\ Tistoriográfica}

\section{Identidades em questão - resenha de "Sobre o relativismo pós-moderno e a fantasia fascista da esquerda identitária", de Antonio Risério}

02 novembro 2021 | Resenhado por Tiago Alinor Hoissa Benfica

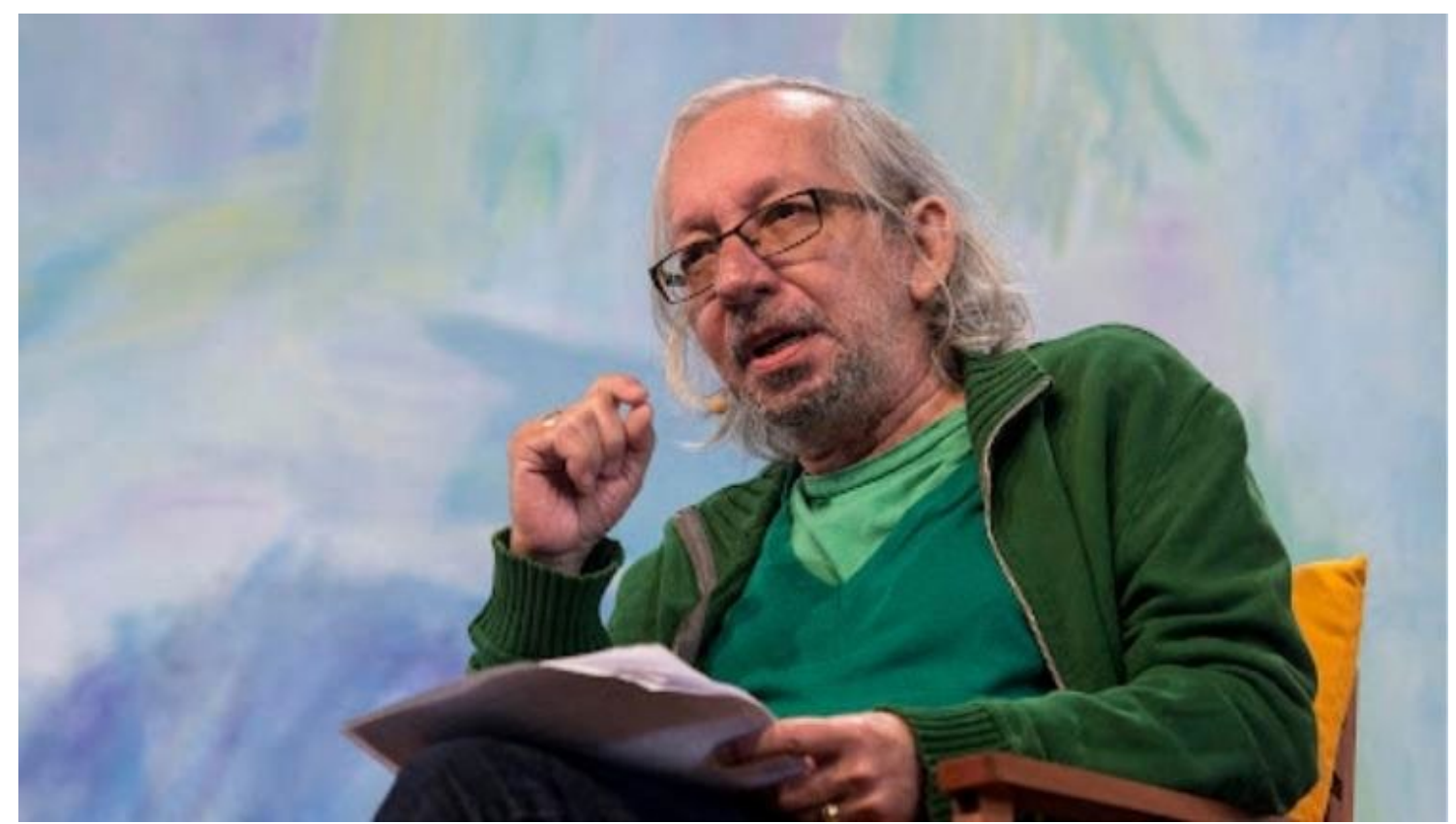

Walter Craveiro

Sobre o relativismo pós-moderno e a fantasia fascista da esquerda identitária não se encaixa nos cânones acadêmicos, mas expressa a existência de uma polêmica direcionada à academia, nos espaços de opiniões homogêneas, onde impera o consenso, no caso, os debates acadêmicos do campo educacional e nas ciências sociais. $\mathrm{O}$ autor Antonio Risério (1953-) é um conhecido polemista que, tendo sido militante estudantil, preso pela ditadura, trabalhado na campanha e nos governos petistas, hoje se proclama crítico da esquerda, que ele qualifica de fascista e identitária. Na sua formação acadêmica ele possui mestrado em Sociologia. Hoje ele se identifica profissionalmente como escritor. 


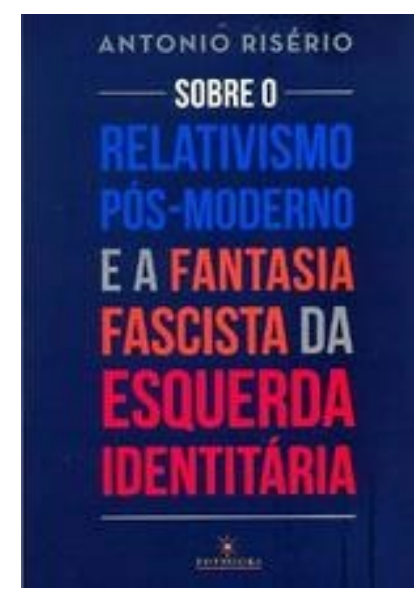

A obra é um ensaio sobre teoria e política, mas o teor é mais político. Ela está dividida em nove seções ou capítulos e os "anexos", que compõem mais de um quarto do livro. Seu estilo narrativo demonstra um sentimento bastante amargo e o uso da palavra ressentimento, em um sentido nietzschiano, empregado para se referir à "politização do ressentimento" por parte da esquerda identitária, também é patente nos argumentos do autor. A sua narrativa não possui uma estética agradável, utilizando-se sem rodeios de palavras de baixo calão, abusando dos parênteses para tentar expor suas ideias, e eu ainda notei a economia no uso de preposições e artigos, o que dificulta o exercício de uma leitura mais suave.

Isso tudo já demonstra que o livro não é acadêmico, pois ele ainda não cita com precisão suas fontes ou as obras ligeiramente referenciadas. Mas o livro exibe discrepâncias teóricas e comportamentais de certos adeptos da pós-modernidade e é uma crítica à academia, feita por meio de autores não "pós-modernos" trazidos à baila, e evoca um conhecimento nada limitado por parte do autor. Um estranhamento positivo que tive ao ler sua obra, da segunda edição, é que ela parece mais bem escrita nos "anexos", quando o autor retoma algumas ideias, do que propriamente o corpo do texto.

O título Sobre o relativismo pós-moderno e a fantasia fascista da esquerda identitária é bastante chamativo, mas discordo do uso indiscriminado da palavra fascista, que se transformou em uma granada de mão para ser jogada para o inimigo. A dita palavra não foi invenção da esquerda, não foi uma "caricatura" originalmente acusativa. Ela foi criada pela direita, na Itália, autodeclarada pelo grupo de Benito Mussolini. No entanto, o campo das Ciências Humanas não gosta muito de respeitar limites conceituais como se observa no perfil da astronomia, que consegue reunir especialistas para definir o conceito de planeta e rebaixar Plutão à categoria de planeta-anão. Nesse sentido, somos anarquistas. Mas diferentes tentativas de definir fascismo dentro e fora da experiência europeia da primeira metade do século XX podem ser encontradas em obras como o Dicionário de Conceitos Históricos (SILVA; SILVA, 2009).

No Dicionário há a referência a autores que detectaram o uso abusivo do conceito "fascista", ou seja, desprovido de critérios ou definições precisas. Antonio Risério tentou se defender das críticas ao defini-lo como uma "tentativa de exercer controle ditatorial sobre a postura e o discurso dos outros, desde que estes manifestem o mínimo teor de discrepância com relação aos dogmas ou à doxa de determinado grupo" (p. 23), algo que eu não concordo. Primeiro que, resguardando a historicidade do termo, mesmo levando em conta a dinâmica da língua, fascismo é coisa de direita. Mas não é por isso que o descarrego acusatório do autor seja desprovido de sentido, pois se trata de uma denúncia das práticas autoritárias enraizadas em nossa cultura, de relações de poder escamoteadas que o autor busca evidenciar em grupos de esquerda. E, partindo do princípio de que toda a cultura é arbitrária, e nela estamos inseridos, nesse aquário os historiadores também se encontram.

Agora, mais uma vez, parece-me totalmente abusivo [1] caricaturar os comportamentos radicais da esquerda acadêmica com o termo fascista, pois, por mais que militantes tratem o pensamento ou a ideologia do outro de modo segregado, por mais que possam não respeitar o direito à diferença de pensamento ou à "outridade", a direita brasileira vai muito além: ela nunca deixou o poder político, e àqueles que a ameaçam, ela busca 
eliminar, seja criando uma série de empecilhos no serviço público, seja negando direitos aos economicamente desafortunados, seja promovendo assassinatos de lideranças de "esquerda", que vai desde o índio que luta na retomada de suas terras, do militante do Movimento dos Trabalhadores Rurais Sem Terra/MST, dos então estudantes universitários presos e torturados pela ditadura militar, a políticos como Marielle Franco. Trata-se aí da eliminação física do outro, um caso limite. E em se tratando de Brasil, dizer que há fascismo de esquerda e de direita é um abuso, pois é como se ambos os valores e comportamentos fossem equiparados, e tal postura já foi analisada no caso da ditadura Argentina por meio da "teoria dos dois demônios"[2]. Portanto, uma coisa é o cerceamento da liberdade de expressão movida por nosso autoritarismo político cultural endêmico, outra coisa é a eliminação física do inimigo ideológico, situação que nenhum liberal ou socialista, cujos ideais se ancoram nos Direitos Humanos, pode concordar. A não ser em uma guerra civil. Acho que não chegamos a tanto, ao menos da parte da esquerda.

Agora, é recomendável a leitura do livro? Sim! Mas é preciso lê-lo criticamente, não no sentido de um julgamento cuja condenação já se vê de antemão, mas no sentido etimológico de "peneira", de separar, para depois avaliar. Como professor de História, na escola de nível básico, e tendo lecionado no ensino superior a disciplina sobre Relações Étnico-Raciais, em faculdades particulares, a leitura do livro permitiu entender melhor a resistência de muitos alunos ao conteúdo que eu lhes trazia. E uma coisa que aprendi recentemente é a refletir mais sobre a palavra dissenso. A depender do perfil dos alunos, as problematizações do tempo presente acerca do racismo são muitas vezes negadas, inclusive muitos deles afrodescendentes. Entre eles há um forte apego à meritocracia, uma ausência no aluno de ensino superior de uma leitura contextualista historicamente embasada, e quando se trata de temáticas indígenas, o preconceito ou falta de conhecimento da realidade é ainda maior. Aliás, as principais dificuldades que tive ao lecionar sobre diversidade étnico-racial se dirigem à religiosidade afro-brasileira e ao respeito simbólico e econômico e das terras indígenas. Digo isso porque a leitura do livro é um contraponto às políticas de reparação étnico-raciais promovidas sobretudo pelo governo do Partido dos Trabalhadores/PT. Assim, o livro possibilita antever a reação - que a esquerda denomina de conservadora - dos alunos, da nossa clientela, com crenças ideológicas bastante enraizadas, que muitas vezes me fizeram reagir de modo beligerante, e hoje vejo que isso não foi a estratégia mais inteligente.

O leitor pode concordar ou não com o autor acerca da leitura sobre os movimentos sociais, que é bastante superficial sobre o caso do Brasil, mas o autor contribui para o debate ao apontar as importações teóricas dos esquemas explicativos advindos dos Estados Unidos da América - designadas como "colonização da academia" -, e com a crítica da forma de enfrentamento às questões de raça daquele país que foram tomadas para serem aplicadas à realidade brasileira. $\mathrm{O}$ autor é forte opositor das interpretações das teorias chamadas de "pós-modernas", que desconstroem as metanarrativas de projetos sociais com vista à transformação da realidade social para deixar brotar preocupações de grupos específicos, ao que Risério chama de formação das nanocomunidades, produzindo uma guetificação, que partiria da universidade. Dentre os vários termos utilizados como categoria acusatória, também se destacam o de neonegros - a ideia de uma pureza negra livre da cultura ocidental -, e de o radfems - radicais feministas.

O contraponto teórico da obra chama atenção, não só pela recusa do autor quanto ao paradigma predominante nas ciências sociais brasileira, mas também por trazer outras referências, demonstrando a existência de dissensos teóricos de autores de várias 
nacionalidades. Isso é curioso, pois raros são os casos de embates teóricos na atualidade. Daí que faz sentido o termo da guetificação na academia, da formação de grupos intelectuais, que se apropriam de apenas uma linha teórica e dela se cercam, ou melhor, passam a estar rodeados apenas pelos apoiadores, muito apropriadamente chamado de "pares". A ausência de ponderações divergentes acaba por produzir a sensação de culto ao progresso, ao novo e à novidade, pois, as discussões teóricas nas Ciências Sociais parecem ser colocadas como evolucionistas, em que depois do moderno veio o pós-moderno, e agora vemos o sucesso do "decolonial". Sobre esses "guetos", grupos de pesquisa e grupos de poder que emergem nas Ciências Humanas, que se reflete no comportamento da militância política, a qual se dirige as palavras do autor, sua crítica não é totalmente desprezível: "esses identitários se fecham como adversários furiosos da diversidade, desfechado um combate feroz e sem tréguas à outridade (...) a belicosidade, o foguetório revolucionarista, etc., com sua recusa do outro, transforma potenciais aliados em, no mínimo, adversários potenciais”. (p. 69, 138).

Nesses tempos de fake news, palavra que o autor não se utilizou, chama a atenção o retorno da discussão da concepção de verdade. O argumento de que há múltiplas epistemologias, todas elas envoltas de ideologias, com sua historicidade própria, defendida por grupos sociais distintos, é bastante utilizado para se referir à "recusa da racionalidade iluminista e da ciência moderna" (p. 26); os tempos atuais parecem acenar uma reviravolta, pela ideia mesma que a ciência possui uma objetividade, que há critérios a serem estabelecidos universalmente para que haja um conhecimento cuja validade independa das ideologias e das culturas, mesmo que carregue e explicite as suas limitações.

A tensão provocada pela pandemia do COVID-19 expôs ainda mais os extremismos ideológicos, e veio na esteira do fundamentalismo religioso, pois ideologias reacionárias fizeram prosperar o movimento antivacina e propuseram tratamentos medicamentosos com eficácia não comprovada ao novo vírus, provocando a reação até de muitos adeptos das teorias "pós-modernas", com o ato de tirar do armário palavras julgadas ultrapassadas como a de "fato", "documento", "prova". Dito isso, concordo que igualar a epistemologia ao nível de uma categoria discursiva assim como outras, desprovida de uma objetividade, precisa ser revista. É necessário dissociar a epistemologia da axiologia, para que o debate sobre os valores ganhem maior legitimidade e que as batalhas ideológicas não se rendam à era da "pós-verdade", para então disputar os corações dos leitores, estimular a sensibilidade com suas estéticas.

O livro Sobre o relativismo pós-moderno mostra que a crítica ao "marxismo cultural" não é apenas proveniente da direita reacionária. Risério discute esse termo fazendo um elogio ao marxismo econômico, que propunha uma utopia universalista, e ataca a atual esquerda que converteu seu espírito sacerdotal [3] salvacionista da humanidade para defender grupos segmentados que se agrupam nas discussões racialistas e sexistas, ou melhor, sobre raça e sobre gêneros sexuais.

Contra a guetificação da academia e de comportamentos políticos, Antonio Risério faz o elogio à mestiçagem brasileira, ao mito da democracia racial que impôs a cultura europeia e pouco se importa com frases que possam ser enquadradas como machistas e eurocêntricas, reclamando do distanciamento do conceito de humano no debate político atual. $\mathrm{O}$ autor afirma que as concepções de humanidade, igualdade de direito e liberdade de expressão são valores evocados a partir da Europa ou da sociedade ocidental. Tratase de uma provocação para rebater críticas vagas ao eurocentrismo, notando que os valores da sociedade ocidental - assim como toda cultura - são dinâmicos e não são 
homogêneos, e que práticas bárbaras e opressivas, presentes em muitas sociedades na atualidade, são escamoteadas na crítica ao eurocentrismo.

O autor combate a ideia de "lugar de fala" que, no seu entendimento, transformou-se em aparato discursivo de poder, de reserva ou mercado/da palavra. Uma definição mais precisa de sua crítica ao "lugar de fala" foi uma citação de Fernando Coscioni, professor de Geografia, retirada da conta do Facebook do mesmo: "para ter legitimidade no que diz, você precisa ser pertencente a um desses grupos de 'oprimidos', com a 'fala legítima', senão, mesmo que você diga algo razoável, você será escorraçado como um 'opressor'” (p. 88). Parece-me que é essa a concepção captada pela "direita". Risério sabe que a ideia original de "lugar de fala" se referia a um constrangimento da posição de classe, desenhado pelo lugar ocupado pelo indivíduo, que lhe possibilitaria uma visão particularizada do entendimento, com uma conotação positiva da experimentação do sujeito e seu discurso, assim como uma limitação do grupo diante da hierarquia social. O autor, em síntese, ressalta que o radicalismo no comportamento da "esquerda identitária" provocou um efeito colateral na direita: "o fascismo identitário provoca o recrudescimento do fascismo de direita" (p. 140).

Mas afinal, como pode ser lido o livro em questão? De um lado, o texto pode ser entendido como uma obra ideologicamente inclinada à direita reacionária para atacar a esquerda. De outro, ele pode ser um entendimento útil para a esquerda perceber como pensa o outro, para refletir sobre o porquê de seus ideais salvacionistas dos oprimidos serem recusados por uma grande parcela da sociedade e assim não ser pego despreparado, para, sendo bastante utópico, a esquerda fazer autocrítica. Há ainda uma terceira possibilidade, dirigida à esfera teórica nas ciências sociais, com a apresentação de discussões de autores que pensam diferente, que não aceitam com suavidade a proposta de interpretação "pós-moderna", sobretudo da vertente foucaultiana. De toda a forma, reflete bem os nossos tempos de polarização, já que o próprio autor pendula entre inclinações à direita e elogios à disposição da revolução social do velho marxismo.

Notas

1. Sobre a definição de história abusiva, ver MENESES, Sônia. Uma história ensinada para Homer Simpson: negacionismos e os usos abusivos do passado em tempos de pósverdade. Revista História Hoje, v. 8, nº 15, p. 66-88, 2019.

2. Sobre "la teoría de los dos demonio", ver GONZÁLEZ, Paula. La última dictadura argentina en el aula: entre materiales, textos y lecturas. Revista História Hoje, v. 7, $\mathrm{n}^{\circ}$ 13, p. $60-82,2018$.

3. Sobre os conceitos de sacerdote e de ressentimento, ver NIETZSCHE, Friedrich W. $A$ genealogia da moral. Tradução Antonio Carlos Braga. $3^{a}$ edição. São Paulo: Editora Escala, 2009.

\section{Referências}

SILVA, Kalina Vanderlei; SILVA, Maciel Henrique. Dicionário de conceitos históricos. 2ed. São Paulo: Editora Contexto, 2009. 
Sumário de Sobre o relativismo pós-moderno e a fantasia fascista da esquerda identitária

Nota do autor

1. A violência rouba a cena

2. O !outro!: do reconhecimento à rejeição

3. Caminhos para a cracolândia mental

4. A racionalidade planetária

5. Abolição da história e das classes sociais

6. A defesa do apartheid político e cultural

7. A bolha neonegra, o afro-oportunismo

8. A onipotência do palavreado

9. Superar o apartheid, reencontrar a democracia

Anexos - Minirrecado ao eventual leitor ou leitora

1. Entrevista a Luciano Trigo

2. De olho no "lugar de fala"

3. Chega dessa conversa de Brasil e de brasileiros?

4. Colagem-Posfácio: de olho em algumas questões

\section{Resenhista}

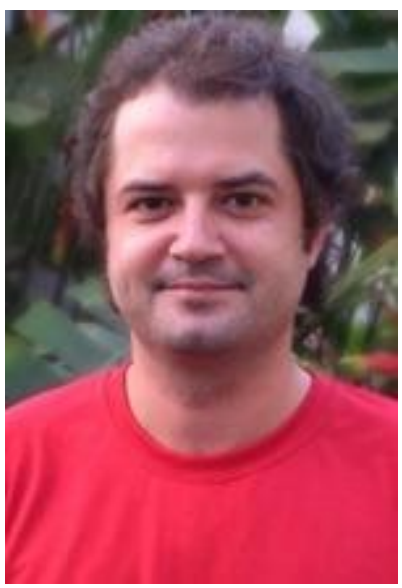

Tiago Alinor Hoissa Benfica - Doutor em História pela Universidade Federal da Grande Dourados (UFGD) e professor de História no ensino básico da Secretaria de Estado de Educação (SEDUC-MT), cidade de Sinop. Publicou, entre outros trabalhos, História e universidade: a institucionalização do campo histórico na Universidade Estadual de Mato Grosso/Universidade Federal de Mato Grosso do Sul (1968-1990) (2016) e Tempos autoritários e militância intelectual: posicionamentos políticos e temas sensíveis na Revista História Hoje (2017-2019). Email: tiagoalinor@gmail.com.

\section{Para citar esta resenha}

RISÉRIO, Antonio. Sobre o relativismo pós-moderno e a fantasia fascista da esquerda identitária. 2ed. Rio de Janeiro: Editora Topbooks, 2020. 199p. Resenha de: BENFICA, Tiago Alinor Hoissa. Identidades em questão. Crítica Historiográfica, Natal, v.1, n.2, nov./dez. 2021.

\section{Baixar esta resenha em PDF}


Outras resenhas de Sobre o relativismo pós-moderno e a fantasia fascista da esquerda identitária

Eli Vieira - Amálgama (2019)

A. Sérgio Barroso - Vermelho (2020)

(C) - Os autores que publicam em Crítica Historiográfica concordam com a distribuição, remixagem, adaptação e criação a partir dos seus textos, mesmo para fins comerciais, desde que lhe sejam garantidos os devidos créditos pelas criações originais. (CC BY$\mathrm{SA})$ 


\section{Definindo História Pública - resenha de "Public History and School: International Perspectives", de Marko Demantowsky}

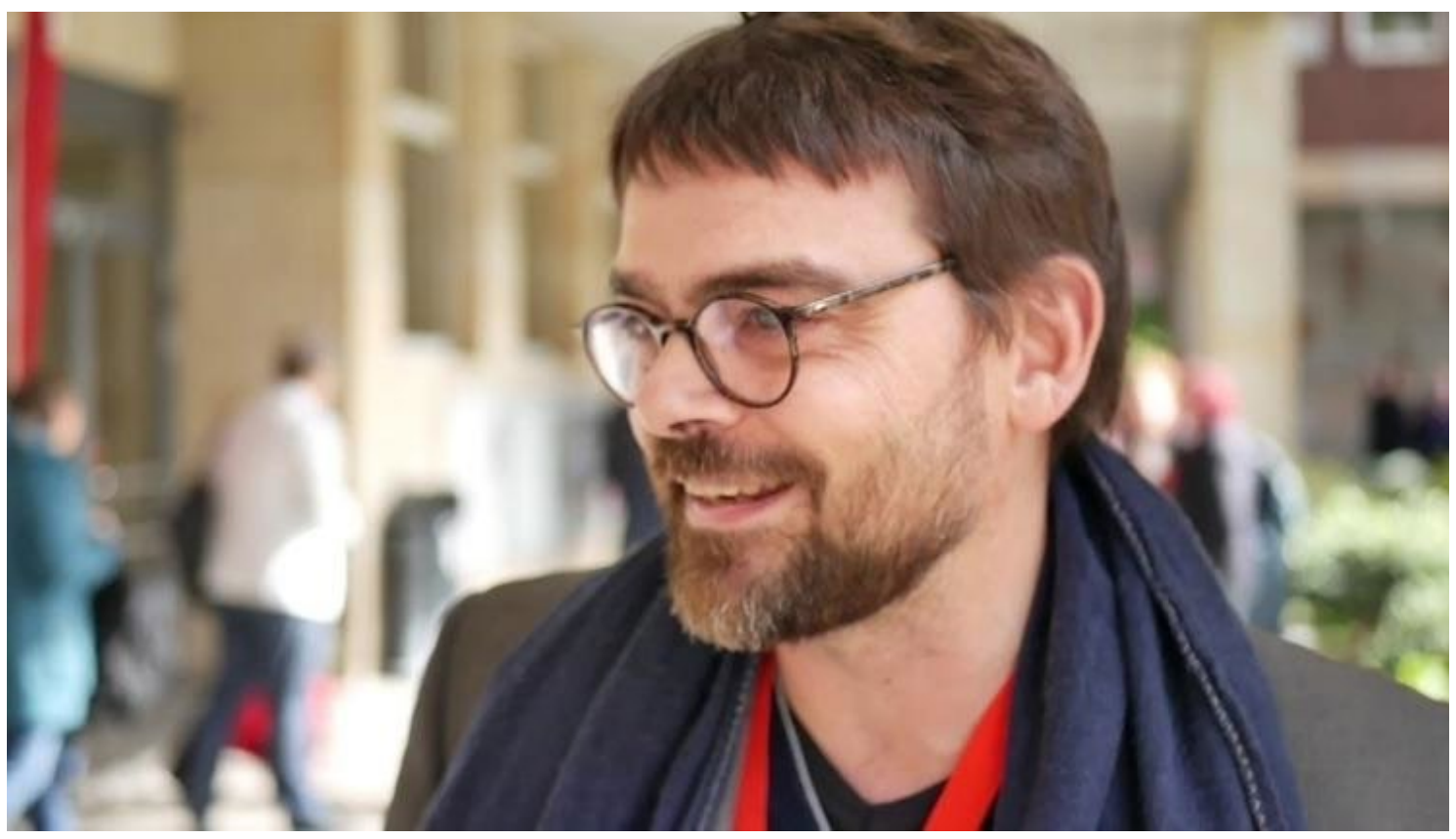

De Gruyter

Em Public History and Scholl Marko Demantowsky discute a relação entre o campo acadêmico (História Pública) e a instituição socializadora (Escola) a partir de uma premissa conhecida de todos nós: a escola pública foi criada no século XVIII para servir à construção da identidade nacional, e as disciplinas literatura, religião e história são os veículos desse ensinamento, ou seja, são responsáveis pelo cultivo de certa "autocompreensão nacional" (p.vi). 


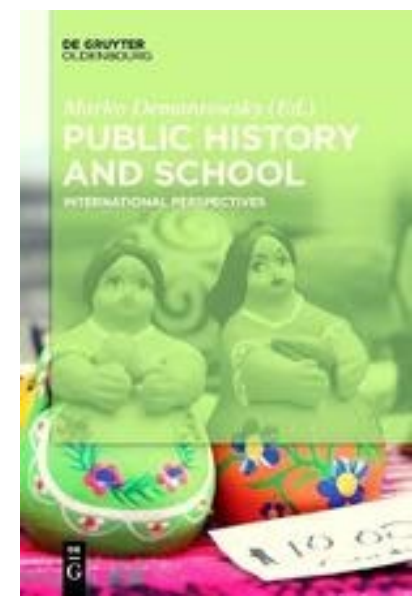

Demantowsky é editor da Revista-Blog Public History Weekly e professor de Didática em Ciências Sociais na Universidade de Basel (Basiléia-Suíça). Foi nesta condição e motivado pela dificuldade de ampliar as possibilidades de pesquisa em história pública em contexto multilíngue que reuniu especialistas para discutirem os quatro temas que constituem a coletânea, começando com a terminologia da área. O que significa "História Pública"? A resposta é mediada por duas outras questões: Os diferentes profissionais que atuam no cultivo da identidade nacional (museólogos, arquivistas, patrimonialistas, memorialistas) se conhecem uns aos outros o bastante e no contexto daquela função da escola? Esses profíssionais estão conscientes do caráter duradouro e exemplar da "educação escolar" sobre as "histórias públicas". (p.vi).

Observem as diferenças entre os termos, transladados do original: "history lessons", "history education", "Public history" e "Public histories". A semelhança morfológica e a dissemelhança semântica provocam um pequeno desconforto no leitor. A introdução de Demantowsky explica essa diversidade e propõe um termo conciliatório: História Pública deve ser um conceito "guarda-chuva". História Pública deve ser uma denominação que auxilia pessoas de comunidades linguísticas diferentes a partilharem um mesmo conjunto de questões e a organizarem-se em grupo de pesquisa.

Quando deixa de ser uma aspiração de Demantowsky e passa ao papel como um corpo de teoria, a definição da História Pública ganha a seguinte expressão: trata-se de um "campo científico" que tem por questão central a constituição dos discursos de identidade individual e coletiva. História Pública é um campo que estuda as "narrativas básicas". É um campo que aborda "as estruturas de identificação [narrativas básicas] da de opinião e significado das sociedades". (p.19) Enfim, "História pública é um complexo discurso identitário relacionado ao passado, operado por indivíduos e grupos no reconhecimento mútuo de narrativas" (p.26).

Limitado o objeto, Demantowski sugere os demais elementos identificadores do campo: a ética e os domínios de ação e os testemunhos da HP. A "ética da História Pública" exige que sejam garantidas a pluralidade de tais discursos e a possibilidade de os seus consumidores se desviarem e até os rejeitarem. (p.27). Quanto aos domínios de ação dos pesquisadores ele os exemplifica com projetos que combinam análises de "ofertas", de "usos e crenças, de "formação" e de "aplicação". Esse programa e consequentes projetos somente podem ser executado de modo interdisciplinar: se o campo trata de "questões fundamentais da convivência humana, da civilização, do passado e do presente", ele reitera, é impossível propor tais questões "dentro de uma única disciplina científica" ("Antropologia, Sociologia, Filosofia, Ciências históricas e educacionais, incluindo a Psicologia"). (p.28). Por fim, Demantowsky identifica as fontes desses discursos de constituição identitária: 1. os "papeis sociais" determinados pelas narrativas básicas; 2. as "regras sociais e linguísticas das narrativas básicas"; 3. a "mídia das narrativas básicas" que promove a interação social; e 4. os "rituais" da narrativa básica (p.26).

A seção inicial é dedicada à História Pública na sala de aula de História. As experiências vêm da África do Sul, da Áustria e da Alemanha. No primeiro texto, a História Pública é a narrativa consumida pelos não escolares e a história escolar, como o 
nome sugere, é a narrativa consumida pela totalidade dos alunos no interior da escola. No texto "História pública e currículo escolar", Rob Sieborger examina a relação entre as duas histórias e o modo como a primeira pode figurar no currículo escolar, sem os vícios da repetição de conteúdo substantivo por todos os níveis de ensino, desprovido das respectivas progressões das aprendizagens. O exemplo é o currículo de História da África do Sul, antes e depois do Apartheid (ou sob o domínio de duas narrativas de grande assentimento popular: a história da "Grande Jornada" e a história de Nelson Mandela). Sua tese é a de que a História Pública migra para a o ambiente escolar, mas deve ser corrigida com os conceitos e procedimentos justificados, por exemplo, pelo que nós entendemos como Psicologia cognitivista da aprendizagem. Outra relação explícita entre os objetos História Pública e Ensino de História está no texto de Christoph Kühberger. Em "Uso privado da História pública e seus efeitos em sala de aula", ele concebe a História Pública pelo produto e pela qualidade do produto, ou seja, ele pensa que comerciais e séries de TV veiculados na Suíça são representações acríticas do passado (produzidas sem as regras do historiador acadêmico). Essas representações moldam, cotidianamente, a forma de as pessoas interpretarem o passado e migram (produtos e formas) para o interior da escola. Considerando o Ensino de História como baseado em regras acadêmicas de interpretação do passado (carreadas de historiadores acadêmicos), o papel do Ensino de História é usar crítica e produtivamente essa História Pública que migra para o interior da escola. No encerramento da seção Cord Arendes discute a aprendizagem e a compreensão da História Pública "como parte da educação histórica profissional nas universidades alemãs" e conclui: é objeto de pesquisa e disciplina de ensino. Contudo, diferentemente do que ocorre nos países de língua inglesa, que "não incorporam" ou "incorporam marginalmente" o Ensino de História "em sua definição" (p.60), na Alemanha História Pública está sob a esfera de influência de outro objeto e disciplina acadêmica: a "Didática da História". Neste texto de Arendes, História Pública é definida como procedimento (exercício de pesquisa e ensino por projetos) que aproxima a pesquisa histórica às práticas de "comunicação" ou de "Transferência de conhecimento" (nota 33). O fechamento dessa seção não faz justiça aos três capítulos. A responsável, Daisy Martin, resume os três textos e conclui, mas não se posiciona sobre a relação Ensino de História/História Pública para além lugares comuns do tipo: a introdução da História Pública no ambiente escolar permite que "os alunos desenvolvam habilidades de pensamento histórico, enquanto aprofundam a compreensão de tópicos e de questões históricas particulares". Os comentários e conclusões que encerram as seções seguintes também decepcionam pelo pouco ou quase nada que acrescentam às conclusões de cada trabalho.

A segunda seção, também composta por três textos, anuncia a escola como objeto da História Pública. O primeiro - "Imaginando a nação através das narrativas mestras da história escolar" -, escrito por Mario Carretero, pouco contribui para a questão. Não define História Pública e não explicita a escola como seu objeto. O texto de Marco Zerwas - "O concurso German Federal President's History" explora competições nas quais os governos alemães, há mais de 50 anos, estimulam estudantes a escreverem histórias focadas em seu entorno. Para Zerwas, o sucesso do empreendimento demonstra que os alunos são produtores de história. Os concursos são considerados grandes estimuladores do engajamento do público com a [História Pública], com os métodos de história e com a história local. O terceiro texto - "Historiadores públicos em sala de aula", como o título indica, defende que professores de História são "historiadores públicos" porque levam para a sala de aula uma série de narrativas consumidas fora dos cursos de formação, fundamentadas na "memória coletiva" e na "história oficial" sobre a nação. Por nossa leitura, fica subentendido que Robert J. 
Parkes vê a necessidade de corrigir o emprego dessas histórias no ensino escolar. É necessário dotá-las de "perspectivas críticas" e de "orientação histórica" no sentido do autorreconhecimento dos alunos como sujeitos. Em outros termos, Parkes reivindica um Ensino de História (ou um Ensino de História Pública) que concilie a finalidade de provedor da "alfabetização histórica" e a finalidade de provedor de "identidade". Por esse texto, novamente, aparece a figura do professor de história como um "historiador público" desprovido das habilidades de julgamento (acrítico).

A terceira seção do livro aborda as implicações da "Política da História" (a determinação dos conteúdos escolares de história via políticos e partidos) na "História Pública" escolar. Nesta parte, um lugar comum é afirmado por Peter Gautschi. Em "Ensino de História na mira do Partido do Povo Suíço", ele defende que a Política (ou cultura política, ou ideologia partidária dominante etc.) determina finalidades, conteúdos substantivos e ideias de aprendizagem do ensino de história na escola. Não há definição de história pública. Essa insuficiência não foi repetida por Thomas Hellmut, autor do capítulo seguinte - "Integração nacional e a ideia de 'Zweckrationalität" [racionalidade de propósito, de fins]. Ele compreende que o Ensino de História é responsável pela socialização da geração mais jovem e narra a experiência austríaca. Depois de experimentar um tempo de Ensino de História voltado para a "doutrinação democrática", a História Pública (talvez entendida como um discurso liberal de esquerda) e os gestores da educação pública devem corrigir os problemas da nova fase - do Ensino de História voltado para a "Cidadania ativa". Deve retificar o ensino porque a nova fase, guiada pela introdução da "Didática da História" como disciplina científica na Áustria, tem também os seus problemas: o "utilitarismo econômico da sociedade burguesa", o conteúdo factual fragmentar e, correlatamente, a despreocupação com as instâncias econômica, social e cultural mais amplas. Assim, professando um Ensino de História comprometido com a "autodescoberta e a autorreflexão" e o desenvolvimento do interesse do aluno "pelo mundo e pela sociedade, Hellmuth reserva à História Pública (não definida) esse papel de corrigir a "Didática da História" normalizadora do Ensino de História. O último texto - "Se eles são motoristas de taxi - o que somos nós? Arquivistas e escolas", de Jan Hodel - atribui outra função à História Pública, neste caso à História ensinada em espaços públicos não escolares, como os arquivos. Hodel reconhece que ambos os espaços (escolar e arquivístico) dão a oportunidade de as pessoas aprenderem com o passado. Mas a limitação das finanças (para os arquivos) e a limitação de horas (para as escolas) tornam as duas instituições concorrentes. A forma de resolver o problema é unindo as duas atividades em um outro lugar: o currículo.

A última seção - "O futuro da História Pública" -, aparentemente menos rendosa para os nossos interesses, toca também nas interações entre rubricas e campos de História Pública e Ensino de História. Nessa parte, os dois autores narram experiências com a formação dos profissionais da História Pública. Evidentemente, as propostas de formação têm a ver com o significado de História Pública professados por seus empreendedores. Para Alexander Khodnev, que escreveu sobre contexto russo, História Pública é uma forma de representação do passado não produzida por historiadores universitários, veiculada por mídias (fora do controle desses historiadores acadêmicos sites para professores de história na Internet, filmes, imagens etc.). $\mathrm{Na}$ era Vladmir Putin, ele afirma, a História Pública sofre a concorrência da "Política na História" (produção acadêmica orientada a construir uma memória de interesse estatal). Ele informa que a História Pública é explorada como curso de Mestrado, mas deve ser ensinada em nível de bacharelado, inserta em cursos de Didática da História. Nessa 
situação, a História Pública proveria a Didática com o ensino sobre "memória histórica coletiva", modos de "divulgação dos fatos históricos no espaço público" etc. (p.200). Charlotte Bühl-Gramer vai além. Ela defende a introdução da História Pública no currículo da educação escolar. Ao justificar o seu intento, praticamente apresenta finalidades caras ao Ensino de História em várias partes do mundo: "História Pública na escola pode encorajar os alunos a consumir história e a participar ativamente da escrita da história pública" e "ensinar os alunos a desconstruir narrativas de história pública, ou seja, desconstruir as representações de outros" (p.202-203). A História Pública, segundo a autora, estimula o emprego da "lógica da apresentação" (que difere da "lógica cientifica"), centrada na apreciação estética e não apenas no conhecimento. Ela defende, por fim, que uma mudança no meio ("de entrega") implica em uma mudança "na própria História Pública”, mas não larga mão das habilidades críticas (da lógica científica) que os escolares devem desenvolver.

O encerramento é muito mais rico. Em "Identidade profissional e propósitos públicos da História", Alix Green faz crítica contundente à configuração fragmentada dos experts (professor, historiador acadêmico, arquivista, curador etc.) à distância entre professores de história da escola básica e professores de história de cursos superiores de História que enfraquece o poder de cada uma dessas categorias de experts nos embates com os governos sobre a gestão da memória e do ensino de história. Também critica o geral entendimento de que o "status" e a "Autoridade" dos historiadores sejam elementos substantivos e permanentes, como "posses" ("credenciais"). Ele reclama que a "autoridade" e "influência" dos especialistas não é uma "entidade substantiva" com fim em si mesma, uma "posse" (como "credenciais". A autoridade dos historiadores é 'construída contingentemente' e deve ser continuamente renegociada com aquele de cujo reconhecimento nosso status de especialista depende", ou seja, os "colegas, alunos, financiadores e leitores", por exemplo (p.177). O endereço é dúbio. Não sabemos se ele mira os historiadores acadêmicos ou se mira os historiadores públicos (para que não repitam os erros dos historiadores acadêmicos). Mas vale, sobretudo, para os brasileiros, envolvidos recentemente com os debates sobre a Base Nacional Curricular Comum e em torno do Projeto de regulamentação da Profissão de historiador.

As quatro seções do livro são perspectivas e exemplificações de experiências com História Pública e Ensino de História na Europa e na África que demonstram o esforço de um grupo de profissionais em torno da construção de uma agenda transnacional e transdisciplinar de pesquisa. As possiblidades de emprego da proposta de Demantowsky são limitadas, evidentemente, a configuração dos sistemas educacionais, dos modos de formação de professores, do lugar acadêmico ocupado pela investigação sobre fins e conteúdo da disciplina escolar História e forças ideológicas dominantes sobre a gestão da memória em cada um dos citados países. Como são reduzidos os exemplos, até mesmo em termos de Europa, é difícil avaliar a viabilidade da construção desse campo. Mas podemos afirmar que os relatos de experiência e o ensaio conceitual já são contribuições muito ricas (talvez as melhores nos últimos cinco anos) para nós brasileiros, autodeclarados estudiosos e/ou praticantes de história pública e do ensino de história na escola básica. Façamos, então algumas extrapolações.

Demantowsky quer "estender pontes". Qual a contribuição dessa atitude para os estudiosos da História pública no Brasil que atuam em contexto monolíngue e antropofágico? Se a intenção de quem milita na (e pela) História Pública é ampliar as possibilidades de diálogo e de investigação, é proveitoso assumir as reservas do coordenador do livro e autor da introdução. Uma delas é fazer avançar um espaço político dos praticantes de História Pública buscando compreender os significados de 
outros conceitos guarda-chuva que se mantém há décadas no Brasil, como rubrica identificadora de grupos "de lealdade acadêmica" que reúnem centenas de pesquisadores e com altíssima capilaridade nas universidades brasileiras. Referimo-nos, evidentemente, à rubrica "Ensino de História". É salutar não repetir (com sinal trocado) o que ocorreu com o conceito e, depois, o campo de estudos sobre "História do tempo presente", afirmado como prática do historiador, desde o século XIX. É salutar, por fím, não repetir o que aconteceu com o conceito guarda-chuva brasileiro de "ensino de história", que resiste ao conceito de "Didática da História", mas quase substituído pelo conceito de "consciência histórica" - conceito que remete "uma" situação concreta no interior de "algumas" regiões alemãs e produzido por "um" autor (Jörn Rüsen).

A segunda contribuição está na experiência do outro - o outro alemão, suíço, sulafricano, austríaco e russo no que diz respeito aos modos de relacionar as duas rubricas indicadoras de domínio acadêmico. Claro que não encontramos duas definições idênticas de História Pública, embora encontremos várias referências ao Ensino de História a partir das finalidades que este cumpre nos sistemas nacionais de educação pública (construir ou desconstruir discursos identitários). Mas é possível perceber diferentes atitudes em relação às referidas categorias. Tomando o Ensino de História como primeiro objeto - e considerando os contextos descritos no livro -, constatamos que o Ensino de História, quando praticado acriticamente e/ou focado no fornecimento de identidades, concilia com História Pública, entendida esta última como processo de alfabetização histórica (Parkes). Vimos também que o Ensino de História corrige História Pública (Kuhberger) e, por fim, que o Ensino de História produz História Pública (Zerwas). Tomando agora o objeto de maior frequência na coletânea como primeiro termo da relação, constatamos que a História Pública completa Ensino de História (acrítico, desprovido de teoria da história) e que o Professor de História é também Historiador Público. Constatamos que a História Pública, engajada na formação da cidadania ativa, corrige a Didática da História (focada nas competências) e corrige o Ensino de História do ensino superior (ensinando a investigar e a comunicar). A História Pública também determina o Ensino de História (Gautschi), se transforma em Ensino de História acrítico - corrigindo-o com as concepções de aprendizagem fornecidas pela Psicologia cognitiva (Sieborger) - e se iguala ao Ensino de História (quando praticada nos Arquivos Públicos). Por fim, constatamos, na coletânea, que a História Pública difere da História Popular dado o caráter acrítico desta última.

Esse breve inventário nos estimula a questionar: podemos listar com clareza e de modo convincente os tipos de relação que encontramos no Brasil quando o objeto do texto de livro ou de dossiê de artigo é a História Pública ou o Ensino de História? O silêncio que a pergunta nos impõe em geral, e momentaneamente, nos estimula, por fim, a concluir que relacionar práticas definidas de História Pública e de Ensino de História (mesmo de modo típico ideal) é, provavelmente, a principal contribuição do livro para os "Professores de História" interessados nos problemas, abordagens teóricometodológicas e ideologias dos historiadores públicos como estratégia de consolidação do "campo" do qual fazem parte no Brasil. 
Sumário de Public History and School: International Perspectives

- Front Matter

- Preface - Marko Demantowsky

- What is Public History - Marko Demantowsky

- Parte I. Public History in the Classroom

- Public History and the School Curriculum: Two South African Case Studies - Rob Siebörger

- Learning, and Understanding of Public History as Part of the Professional Historical Education at German Universities - Cord Arendes

- The Private Use of Public History and its Effects on the Classroom - Christoph Kühberger

- Teaching, Learning, and Understanding of Public History in Schools as Challenge for Students and Teachers - Daisy Martin

- Parte II. School as an Institution of Public History

- Imagining the Nation throughout School History Master Narratives - Mario Carretero

- The German Federal President History Competition. A Public History Occasion - Marco Zerwas

- Public Historians in the Classroom - Robert J. Parkes

- Parte III. History Politics, School, Public History

- History Teaching in the Focus of the Swiss People's Party - The Way Policies Take Influence on Schools, too - Peter Gautschi

- National Integration and the Idea of "Zweckrationalität": "Public History" and History Teaching in the second Republic of Austria - Thomas Hellmuth

- If They are Taxi Drivers - What Are We? Archives and Schools - Jan Hodel

- Professional Identity and the Public Purposes of History - Alix Green

- Parte IV. The Future of Public History - What Shall We Teach Perspectively?

- The Future of Public History - What Shall We Teach Perceptively: Russian Situation - Alexander Khodnev

- The Future of Public History - What Shall We Teach Prospectively? Remarks and Considerations - Charlotte BühlGramer

- The Politics of Public History Education - Mills Kelly

- About the Authors 


\section{Baixar gratuitamente o livro resenhado [Link]}

\section{Resenhistas}
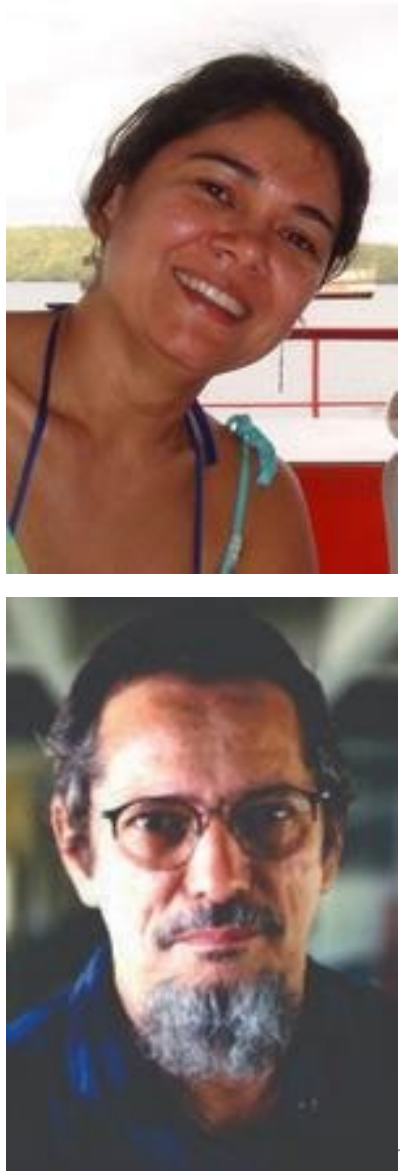

Jane Semeão - Doutora em História pela Universidade Federal do Rio Grande do Sul (UFRGS), professora do Departamento de História da Universidade Regional do Cariri (URCA) e editora do bolg Resenha Crítica. Um "oásis" chamado Cariri: Instituto Cultural do Cariri, natureza, paisagem e construção identirária do sul cearense (1950-1970) e "O que a Austrália tem nos ensinar?" O Tempo Presente nos programas de História produzidos pela Australian Curriculum and Assessment Authority - ANCARA (2008-2013). Email: janesemeão@globo.com

Itamar Freitas - Doutor em História (UFRGS) e em Educação (PUC-SP), Professor do Departamento de Educação e do Mestrado Profissional em História, da Universidade Federal de Sergipe, e editor do blog Resenha Crítica. Publicou, entre outros trabalhos, Uma introdução ao método histórico (2021) e "Objetividade histórica no Manual de Teoria da História de Roberto Pirgibe da Fonseca (19031986)”.E-mail: itamarfreitas@gmail.com.

Para citar esta resenha

DEMANTOWSKY, Marko. Public History and Scholl: International perspectives. Berlin: Walter de Gruyter GmbH, 2018. 230p. Resenha de: SEMEÃO, Jane; FREITAS, Itamar. Definindo História Pública. Crítica Historiográfica. Natal, v.1, n.1,nov./dez. 2021.

\section{Baixar esta resenha em PDF}

Outras resenhas de Public History and Scholl: International perspectives

Paolo Ceccoli - Novecento.org - Didattica dela storia in rete (2019).

(C) - Os autores que publicam em Crítica Historiográfica concordam com a distribuição, remixagem, adaptação e criação a partir dos seus textos, mesmo para fins comerciais, desde que lhe sejam garantidos os devidos créditos pelas criações originais. (CC BYSA) 


\section{A fabricação do projeto acadêmico - resenha de "Práticas de pesquisa em história" | Tania Regina de Luca}

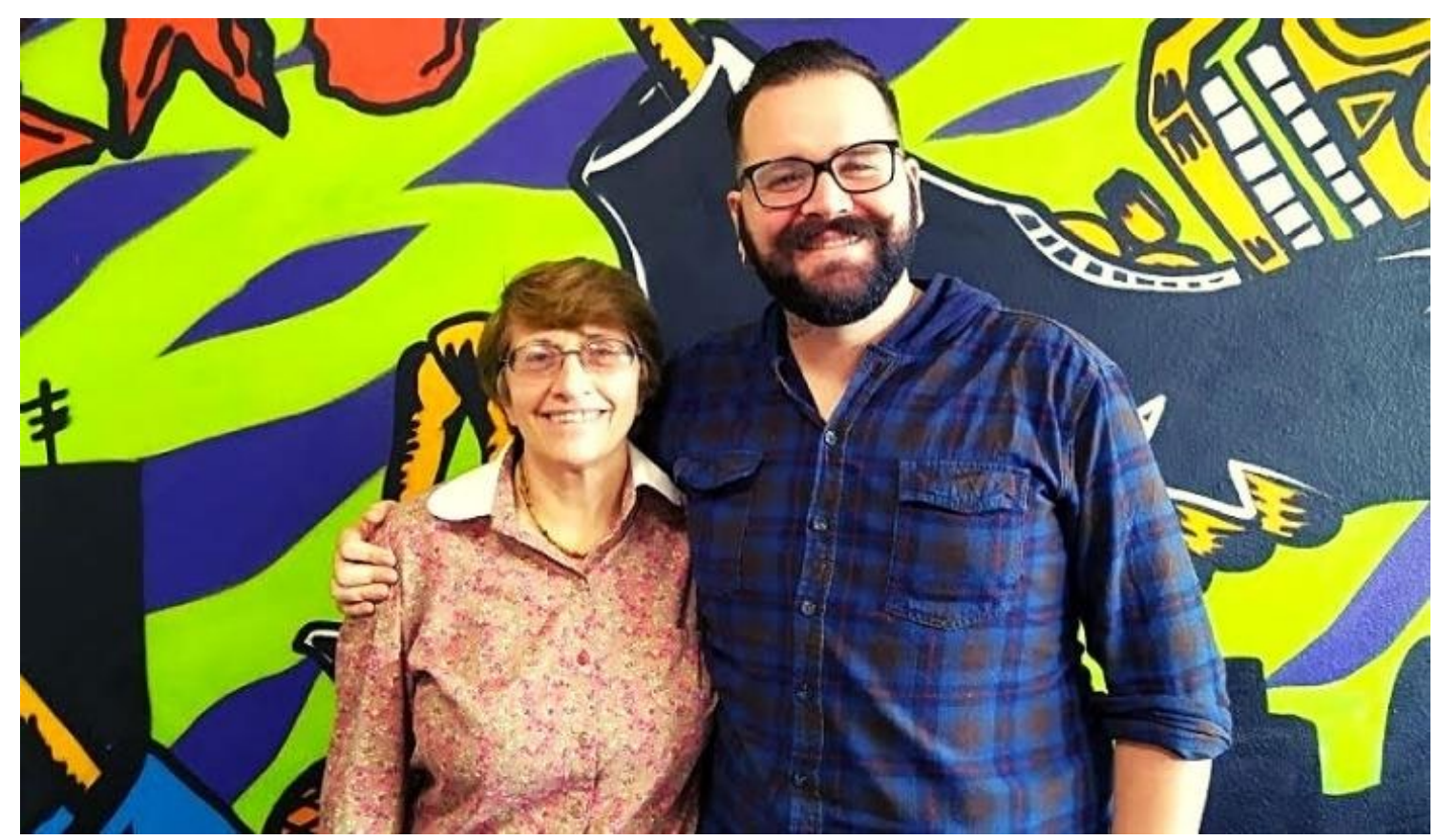

Antena Zero (2019)

Tania Regina de Luca, professora do Departamento de História da Universidade Estadual Paulista Júlio de Mesquita, é conhecida historiadora da imprensa nacional e estrangeira. No livro Práticas de pesquisa em história (2020), parte da sua experiência de pesquisadora é compartilhada, "especialmente", com "estudantes de graduação". Trata-se de um clássico livro propedêutico de investigação histórica e de metodologia científica. 


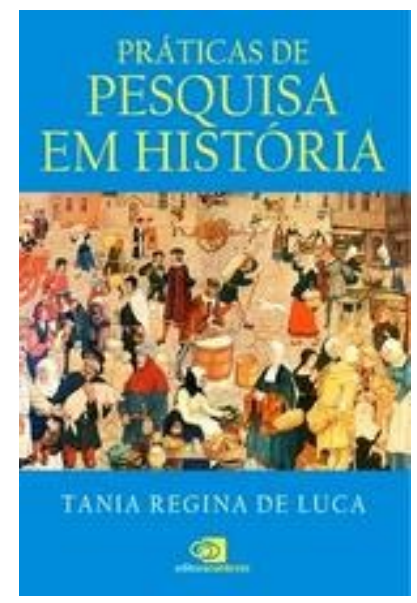

O texto é estruturado em seis capítulos que exploram o fazer do historiador, a ideia de fonte histórica e os passos para a concretização de uma pesquisa acadêmica em história: recorte do objeto, seleção de fontes, construção do texto e do projeto de pesquisa. Segundo a autora, o objetivo da obra é "apresentar, de forma didática, procedimentos e métodos que distinguem a produção do conhecimento historiográfico e, desse modo, incentivá-lo a participar ativamente desse instigante desafio que é escrever História, elaborando e executando o seu próprio projeto de pesquisa." (p.10-11).

A iniciativa já ganha valor imediato por dois motivos. As unidades de leitura traduzem as competências necessárias ao trabalho introdutório na pesquisa histórica. O segundo motivo é o cenário da formação nacional. Em geral, a maioria dos nossos colegas formadores em história é versado em falar muito sobre a sua pesquisa, mas quase nunca a experimentar com os seus alunos, ou seja, ensinar a pesquisar, pesquisando em situações concretas. Contudo, para que o desejo da autora se concretize, contudo, é necessário que alguns equívocos sejam corrigidos, na provável segunda edição do livro.

A começar pela introdução. Se o texto é "didático", deve efetivamente introduzir o leitor à obra, ou seja, definir o objeto (a prática de pesquisa), antecipar a sua função e destinação, justificar a iniciativa, dizer da sua estrutura e justificar o valor funcional das epígrafes.

No todo, não quero apresentar divergências de posição, mas apenas identificar trechos que podem ser melhorados. Digo isso porque o livro é introdutório e trata de matéria tornada senso comum para os profissionais formados nos anos 80 e 90 do século passado, como é o caso da autora.

No primeiro capítulo, corajosamente, a autora reconhece a valência bissecular de certo "método" do historiador e defende o emprego de seus fins e estratégias. Para ficar impecável, basta que exclua um vulgarismo circulante entre os alunos: o combate a ideia de "verdade absoluta" (p.15), dificilmente encontrável em historiadores do século XIX. Basta que defina "método" e, principalmente, que reconheça o papel dos velhinhos franceses, alemães, belgas, americanos e brasileiros nessa tarefa de transformar a crítica documental em traço diferenciador do historiador profissional. No capítulo, são os historiadores Marc Bloch, Lucien Febre e Edward Carr que, literalmente (e em aparente contradição) saem muito bem na foto.

O segundo capítulo historiciza o significado de "documento", explorando posições do século XIX e do século XX. Aqui, o esforço positivo do capítulo anterior se esvai. O texto é iniciado com referências à C.-V. Langlois e C. Seignobos, mas para contestá-los com ironia, em benefício da dupla fundadora da revista Annales e de "expoentes da Micro-História", como Carlo Ginzuburg. Já há matéria brasileira que revê essa ideia de ruptura metodológica e até epistemológica entre a dupla francesa do final do século XIX e a dupla francesa do primeiro terço do século XX. Do jeito que está, a autora reproduz a versão colonizada e (portanto) acrítica, vendida pelos franceses de meados do século passado e por muitos brasileiros paulistas, paulistanos, cariocas e mineiros de até a semana passada. O empenho em louvar os Annales induz a autora (e aos muitos colegas nossos) a omitir que os velhinhos teorizavam de modo tão ampliado como o de Febvre a 
respeito dos documentos e de que, em tese, "história problema" e "história política" não são pares antitéticos, necessariamente.

Outro reparo a ser feito ao capítulo segundo diz respeito à definição de documento. A autora distingue "documento" e "fonte", afirmando que o primeiro "recobre todo e qualquer elemento proveniente do passado" e o segundo "é reservado para o conjunto selecionado e utilizado pelo investigador numa pesquisa científica" (p.36. Grifos meus). Não há menções à autoria da definição, o que me leva a supor que a declaração é mesmo é da lavra de Tania de Luca. Penso que a autora criou uma dificuldade onde, efetivamente não existe. Se observar pelo ponto de vista das línguas ou dos usos feitos por determinado autor (em língua tal e tal) verá que a coisa se explica de modo mais fácil. Tanto é assim que a própria autora abandona a distinção no curso do capítulo, empregando "rastros", "registros", "fontes", "evidências", "documentos", "testemunhos" e "vestígios" sem distinguir o que é "parte" e o que é "todo".

No capítulo terceiro, que trata do recorte do objeto e da leitura de fontes, há dois senões. Divirjo da autora em relação à ordem dos elementos ou às prioridades dos procedimentos. Ela orienta os leitores a definirem temas. Se quisesse manter a coerência com a "escola" destacada no capítulo anterior, deveria pôr o estabelecimento do problema de pesquisa como primeira ideal tarefa do iniciante. A coisa a ser estudada (o objeto material ou intelectual) é a resposta à questão. Escolher tema é um procedimento operatório, disciplinar e didático, criado no interior das universidades. Quando pensamos no trabalho intelectual do historiador, independentemente dessa situação comunicativa, é a inquietação, a insatisfação (manifesta em forma de questão) que aparece como o primeiro elemento da pesquisa.

Na referência à tarefa de ler as fontes, o texto pode ser melhorado se a autora tomar como apoio os princípios éticos anunciados no capítulo primeiro. Pode melhorar ainda mais o texto se estabelecer uma hierarquia entre os gêneros tese, artigo, livro-tese e obras de referência, com base na sua própria experiência de pesquisa. Pode por fim, potencializar o valor do capítulo, dando destaque a um pequeno trecho que trata da revisão da literatura. Ele é triplamente importante. Atenta para o gerenciamento da abundância de informações, para o compromisso com o desenvolvimento consistente dos domínios históricos e para o respeito à produção representativa da área. $\mathrm{O}$ trecho que transcrevo é irretocável. Observe que a autora não põe a titulação, o programa de Pós-Graduação, a Universidade ou o Estado da federação brasileira como critério de citação. Esse princípio deveria ser introjetado como valor não somente por iniciantes, mas por todos os seus instrutores doutores:

É por esse mergulho que o iniciante se aproxima dos pesquisadores que o antecederam, distingue seu s procedimentos e os problemas que se colocaram, as fontes de que se valeram, as maneiras pelas quais as interpretaram, as conclusões a que chegaram, como se posicionaram diante dos impasses do seu próprio tempo. Identifica limites e virtudes que o inspiram a seguir na mesma senda ou interpelar o objeto a partir de outro ângulo, segundo as novas demandas do seu próprio presente. (p.74).

O quarto capítulo oferece bom exemplo de aplicação dos princípios de investigação em situações concretas. Aqui, a autora demonstra a metodologia situada nos estudos sobre o escravismo e aponta as mudanças de rota e os critérios de escolha das fontes, comuns no trabalho do pesquisador experiente. São, porém, dispensáveis o autoelogio e o merchandising da editora no interior do texto autoral.

O quinto capítulo trata da tarefa de escrita. A inclusão de texto do tipo já é motivo para aplauso. Não é comum manual de introdução brasileiro se ocupar da comunicação dos 
resultados da pesquisa. $\mathrm{O}$ trecho a melhorar diz respeito à iniciativa tipicamente formativa de clarificar as diferenças entre narrativas historiadoras, ficcionais e jornalísticas. O princípio da criação controlada atravessa o texto. O capítulo, contudo, pode ser melhorado se a autora matizar essas diferenças, refletindo, por exemplo, sobre os próprios trechos que sugerem contradição, ou seja, revelando os elementos ficcionais da escrita histórica do historiador, a exemplo da escolha pelos marcos temporais finais e iniciais, da periodização, da ação dos personagens e da dimensão da experiência humana a explorar (p.112-113).

Nas últimas partes do livro - o capítulo sexto e as considerações finais - não há muito a louvar ou a reparar. O livro se encerra com referências à qualificação e ao anúncio dos fins da Ciência Histórica e do historiador. $\mathrm{O}$ fato destoante, contudo, somente pode ser percebido quando observamos o lugar do capítulo sexto no plano geral da obra. Afinal, o livro foca nas práticas de pesquisa histórica (heurística, crítica, escrita etc.) ou nas etapas de construção de um projeto de pesquisa? Essa dúvida me leva a considerar que o plano da obra oscila entre oferecer princípios de investigação histórica e procedimentos para a construção de um dos instrumentos da investigação histórica, que é o projeto de pesquisa. Por isso soa estranho que a autora encerre o livro com o projeto e pesquisa, depois de ter dissertado sobre a escrita da história.

Minha apreciação final é de que a obra cumpre os objetivos estabelecidos na introdução e pode, efetivamente, contribuir para a formação dos graduandos em História ou que empregam a pesquisa histórica. Em termos gerais, o texto pode ser bastante melhorado em seus aspectos formais, quando a editora segmentar parágrafos extensos, com 16, 30 linhas, corrigir algumas passagens sem coesão, extirpar erros tipográficos, de pontuação e o uso indiscriminado de itálicos e negritos. Se quiser ampliar a vida útil do manual, os editores e a autora podem atentar para as contradições e as insuficiências apontadas ao longo da descrição de cada capítulo. Podem, por outro lado, justificar as posições ou contra-argumentar no espaço reservado na revista que publica esta resenha.

\section{Sumário de Práticas de pesquisa em história}

- Introdução

- Em busca do passado

- Documentos da certeza à construção

- Da área ao objeto de pesquisa

- Circunscrever as fontes

- texto historiográfico

- Unir os fíos e construir o projeto

- Para finalizar

- Referências bibliográficas

\section{Live de lançamento [Link]}




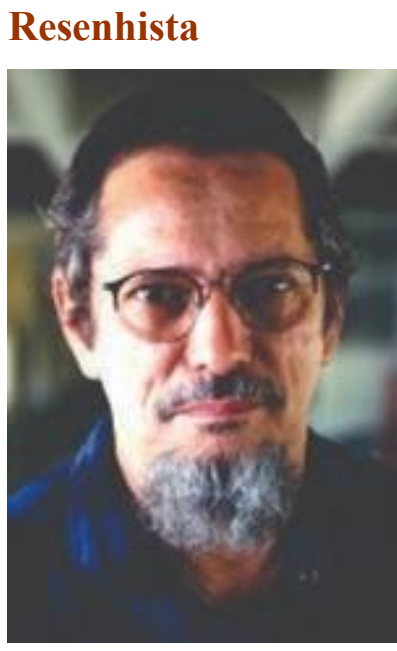

Itamar Freitas - Doutor em História (UFRGS) e em Educação (PUC-SP), Professor do Departamento de Educação e do Mestrado Profissional em História, da Universidade Federal de Sergipe, e editor do blog Resenha Crítica. Publicou, entre outros trabalhos, Uma introdução ao método histórico (2021) e "Objetividade histórica no Manual de Teoria da História de Roberto Pirgibe da Fonseca" (19031986)".Email: itamarfreitas@gmail.com.

\section{Para citar esta resenha}

LUCA, Tania Regina de. Práticas de pesquisa em história. São Pulo: Contexto, 2020. 144p. Resenha de: FREITAS, Itamar. A fabricação do projeto acadêmico. Crítica Historiográfica. Natal, v.1, n.2, nov./dez. 2021.

\section{Baixar esta resenha em PDF}

Outras resenhas de Práticas de pesquisa em história

Gabriel Marques Fernandes - Fênix. Revista de História e Estudos Culturais (2020).

(C) - Os autores que publicam em Crítica Historiográfica concordam com a distribuição, remixagem, adaptação e criação a partir dos seus textos, mesmo para fins comerciais, desde que lhe sejam garantidos os devidos créditos pelas criações originais. (CC BY$\mathrm{SA})$ 


\section{Aprender com jogos - resenha de "Educação Histórica \& videogames", de Helyom Viana Telles}

01 novembro 2021 | Resenhado por Fernando de Souza Cruz

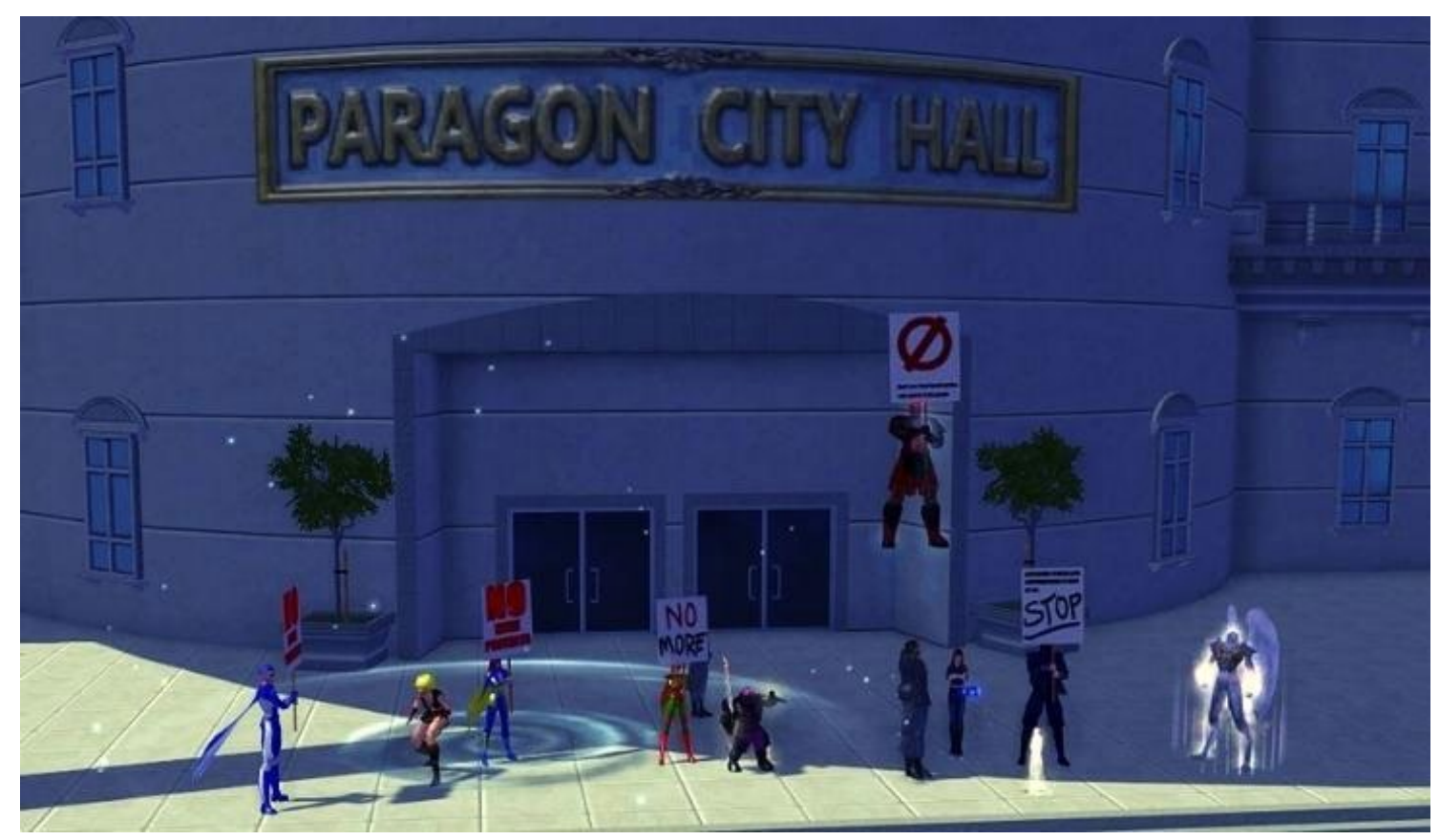

City of Heroes by Cleretic

Existe uma certeza aplicável à educação atual: a necessidade da inserção do mundo digital na educação básica. Essa assertiva aplicada ao Ensino de História permite a utilização dos meios digitais enquanto ferramentas destinadas ao processo de ensinoaprendizagem e, sobretudo, enquanto evidências históricas de um tempo presente experienciadas pelo corpo discente e, por que não, por parte do corpo docente.

Buscando realizar essa conjunção, Helyom Viana Telles apresenta "Educação Histórica \& Videogames" publicado pela Editora Brazil Publishing no ano de 2020. Direcionado a docentes de todos os níveis do Ensino de História - inclusive a quem está em formação -, o livro propõe a utilização de videogames para o estudo da História através do conceito de segunda ordem empatia histórica. 


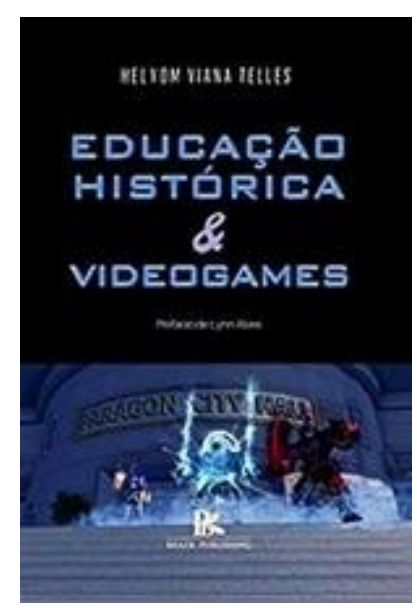

Nas últimas décadas, houve uma profusão de pesquisas acadêmicas sobre o Ensino de História no Brasil. Estabelecido como um campo de estudos, as investigações historicizaramno, identificaram e analisaram as proposições curriculares voltadas à área, apresentaram inúmeras metodologias de trabalho e estruturaram o trabalho com a abundante variedade de evidências históricas disponíveis e utilizáveis em sala de aula. Voltados para o Ensino de História aplicável na educação básica, esses estudos apresentam perspectivas e métodos distintos entre si, mas possuem uma característica em comum: todos foram produzidos a partir da academia. Contudo, raros autores elaboravam academicamente suas próprias inquietações, formulações e métodos aplicáveis ao Ensino de História. Produções que representariam de alguma forma as especificidades de cada realidade escolar (eivadas de precariedade) eram apagadas em currículos e livros didáticos unificadores.

Essa lacuna, começa a ser preenchida a partir da criação do Mestrado Profissional em Ensino de História (PROFHISTÓRIA, 2021), no qual está inserida a obra de Viana Telles (2020). Ofertado em rede nacional, o programa Busca a formação continuada de professores de História voltados para a inovação na sala de aula, ao mesmo tempo que, de forma crítica e responsável, possam refletir acerca de questões relevantes sobre diferentes usos da informação de natureza histórica.

O livro de Viana Telles (2020) é uma adaptação de sua dissertação, defendida em 2018. Como uma adaptação, coube ao autor selecionar as partes que julgava mais importantes e relevantes para atender seus objetivos. A obra é dividida em 6 capítulos, nos quais apresenta uma trama muito bem confeccionada e estruturada de referências acadêmicas discutidoras dos temas propostos.

Os cinco primeiros capítulos mantêm a estrutura típica de uma dissertação de mestrado. Neles, autor historiciza conceitos, localiza-os temporalmente e espacialmente, relacionando muitas leituras de um tema e identificando quais interpretações serão utilizadas em sua produção. O trabalho de aprofundamento conceitual, contudo, passa ao largo das discussões da vida prática em sala de aula, o que pode distanciar o interesse de alguns docentes da educação básica.

No primeiro capítulo denominado "Introdução: a ludificação do passado" o autor apresenta sua trajetória enquanto pesquisador de jogos eletrônicos (p. 20), seu local de trabalho e o que o motivou a enveredar por tal investigação (p. 27). Esse é um recurso demandado por docentes do programa e, comum às dissertações do ProfHistória. Conforme apresentado nos objetivos do programa, espera-se de quem realiza a pesquisa a investigação de sua realidade. Também nesse primeiro capítulo, o autor advoga a necessidade de proposições superadoras de muitas dicotomias que ainda pairam sobre a pesquisa do ensino de história, algumas recorrentes como a História e Ensino de História enquanto saberes separados (p. 25) e outras específicas à relação entre o ensino de História e os videogames: a dicotomia entre o real e o virtual, lazer e saber (p. 29). O 
autor convida o leitor a olhar para os videogames como elementos de uma prática cultural, fornecedores de uma relação específica com o passado. Aliado a empatia histórica, o jogo permite acessar o passado enquanto experiência cognitiva e engajamento emocional.

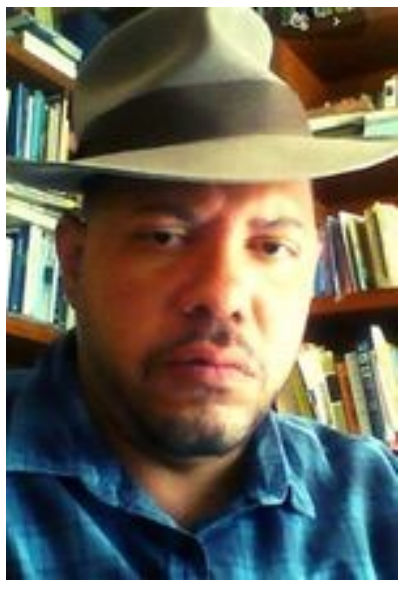

Figura 1 Helyom Telles

No segundo capítulo "Discutindo o ensino de história", baseando-se, principalmente, em Elza Nadai (1993), o autor apresenta o percurso da disciplina escolar história no Brasil, bem como a inserção do Ensino de História enquanto campo de investigação acadêmica que busca compreender uma crise do ensino de história localizada no currículo, nas condições materiais e na desmotivação dos estudantes (p. 44). Esse arco narrativo sustenta a introdução da Educação Histórica, uma forma de ensino-aprendizagem do conhecimento histórico valorizadora dos saberes discentes e das maneiras como estes compreendem o passado. É esse modelo que Viana Telles persegue em sua produção.

No capítulo "Percurso metodológico e pesquisa-ação" o autor define seu trabalho como investigação de base qualitativa a partir da aplicação de uma sequência didática, construída a partir da pesquisa bibliográfica e conceituação do Ensino de História, dos Jogos eletrônicos e da Empatia História (p.49). Viana Telles historiciza a pesquisa-ação enquanto metodologia de pesquisa, ação. Para estudantes de graduação e profissionais em formação continuada, essa descrição é modelar. A segunda parte do capítulo trata do local onde a pesquisa foi desenvolvida (Campus Serrinha do Instituto Federal Baiano), o perfil do público discente com o qual ela foi aplicada ( $3^{\text {a }}$ Série de Agroecologia) e descreve a sequência didática aplicada. Esse trecho revela as razões da escolha do seu produto no mestrado-profissional: um instrumental de avaliação de jogos eletrônicos baseado na empatia histórica.

O quarto capítulo, "Jogos eletrônicos e didática da história", traz uma discussão sobre a representação dos jogos na historiografia. Ressalvando que existem poucas pesquisas que proponham metodologias e formas de avaliação para a utilização dos jogos eletrônicos nas aulas de história (p.78). O autor informa sobre as diferentes abordagens para desenvolvedores de jogos e historiadores e critica a que procura nos jogos eletrônicos veracidades históricas construídas pela historiografia. Ele defende a inclusão desses na Educação Histórica quando adotados enquanto narrativas históricas (p.80). O autor reconhece a criação de um passado imaginado através dos jogos como um consenso entre pesquisadores, ao passo que aponta a lacuna da falta de historicização dos jogos analisados (p.88). Na segunda parte do capítulo o autor localiza a Educação Histórica dentro da teoria conhecida como Didática Histórica para, mais uma vez, justificar a adoção dos jogos eletrônicos em sala de aula. Ele ressalta as possibilidades dialógicas e reflexivas suscitadas por esses em diálogo com o passado. A despeito de sua brilhante argumentação conceitual, faz falta uma breve exposição do mercado de videogames ou do alcance dessas mídias nas juventudes para estimular a inclusão delas nas aulas de história. Segundo a Pesquisa Game Brasil (2021), de 2021, 72\% dos brasileiros têm costume de usar algum jogo digital independentemente da plataforma. Do público em idade escolar (16 - 19 anos), 10\% está habituado com os jogos eletrônicos. Aproximadamente 50\% de quem joga pertence as classes C, D e E (Idem, p. 
15). A pesquisa da GameBrasil informa ainda sobre as plataformas físicas, grande parte joga em smartphones (41,6\%) (GameBrasil, p.10-20). Esse é um nicho possível de trabalhar nas escolas levando em consideração o uso de equipamentos privados de discentes, todavia o livro não envereda por esse caminho.

No quinto capítulo, o autor chega ao cerne de sua pesquisa ao relacionar a empatia histórica aos jogos digitais. O autor entende empatia histórica como conceito de segunda ordem bidimensional. Nesse prisma, o passado é acessado via cognição e via emoção. Assim, o saber sobre o passado através da empatia histórica requer cuidado com a alteridade e o desenvolvimento de uma empatia emocional com as figuras históricas. Para dar conta do empreendimento, o autor revisa uma extensa bibliografia sobre o aspecto emocional da empatia histórica e seus possíveis modelos de aplicação para o ensino de história, defendendo a adoção de avatares [2] como um conceito de segunda ordem. A inovação nessa proposição esbarra na definição do que seriam conceitos de segunda ordem e do próprio desenvolvimento do texto. Para Lee (2005), conceitos de segunda ordem entendidos são "uma camada de conhecimento que está por trás da produção do conteúdo ou substância real da história" (Lee, 2005, p. 32), esses dizem respeito aos conceitos utilizados por historiadores como tempo, mudança, empatia, causa, evidências e relatos. Viana Telles não demonstra como os avatares podem ser um conceito, mas apresenta de maneira clara e objetiva a sua utilização como ferramentas para trabalhar com conceitos de segunda ordem como a empatia histórica e como esses são capazes de evidenciar a bidimensionalidade da empatia. Em um bom exercício de diálogo bibliográfico, o autor submerge nas experiências emocionais proporcionadas pelos videogames, sempre focando no desenvolvimento da empatia para afirmar que é necessário jogar, refletir sobre o desenvolvimento, a narrativa e a produção do jogo e, sobretudo, a experiência de jogar, promovendo espaços para o diálogo. Ao fim, descreve como os videogames compõem as características da empatia histórica formuladas por Endacott e Brooks, a contextualização histórica, a tomada de perspectiva e a conexão afetiva (p. 119).

No último capítulo, Viana Telles apresenta o instrumento criado que reúne os modelos de avaliações de videogames e os modelos de aferição da empatia histórica em um único e extenso instrumental. Ele afirma a necessidade de que docentes escolham e, preferencialmente joguem o jogo a ser utilizado, construindo, ele próprio, sua reflexão sobre o jogo (p.159). O instrumental foi avaliado por duas pessoas que o consideraram de grande valia para professores de História na investigação e utilização de jogos eletrônicos em sala de aula. Um dos resultados dessa avaliação, ausente no desenvolvimento do livro, mas presente na realidade educacional brasileira, foi a impossibilidade de utilização de videogames nas aulas de História. Tanto o avaliador, quanto a avaliadora afirmaram que não poderiam aplicar o instrumental em seus locais de trabalho (p.173). O autor não se aprofunda nessa impossibilidade, afinal seu objetivo era criar o instrumental e submetê-lo a avaliação. Por fim o autor conclama a utilização de seu recurso e manifesta o desejo de aplicá-lo mais vezes e sempre o melhorar.

Apesar do esforço de pesquisa e da engenhosidade do autor, fica em aberto a forma como esse instrumental pode ser utilizado nas aulas de história. O recurso com 67 comandos (p.160-171) por si só demandaria um tempo considerável de preenchimento. Quando somado preparação e análise prévia dos jogos realizada por docentes, sugerida pelo autor, essa preocupação sobre o uso do instrumental se amplia. Se pensarmos 
exclusivamente no nível médio, a não regulação do ensino de história abre um leque para o trabalho interdisciplinar com videogames no estudo do passado e para a utilização do instrumental criado por Viana Telles.

Em uma visão de conjunto, por fim, podemos afirmar que obra de Viana Telles cumpre a maior parte de seus objetivos ao fornecer a docentes de qualquer nível de ensino e estudantes de graduação uma profunda análise conceitual dos temas que balizam sua pesquisa. A leitura de seu texto possibilita não só a compreensão de conceitos como empatia histórica, educação histórica, videogames, ensino de história, mas também o conhecimento dos caminhos e discussões percorridos no desenvolvimento de cada conceito. Defendendo a utilização de videogames no ensino de história a partir da cognição e emoção preconizadas pela leitura do passado através da empatia, Viana Telles apresenta um minucioso modelo de análise dos videogames, a maneira como relacioná-lo ao ensino de história e espera, como outros autores já o fizeram, que docentes se arrisquem a experienciar a utilização de videogames no ensino de história.

\section{Referências}

GAME BRASIL. Pesquisa Game Brasil 2021. Disponível em:

https://materiais.pesquisagamebrasil.com.br/2021-painel-gratuito-pgb21. Acesso em: 20 de set. 2021.

LEE, Peter J. Putting Principles into Practice: Understanding History. In: National Research Council. How Students Learn: History in the Classroom. Washington, DC: The National Academies Press, 2005.

NADAI, Elza. Ensino de história no Brasil: trajetória e perspectiva. Revista Brasileira de História, São Paulo, v. 13, n. 25/6, p. 143-62, 1993.

\section{Sumário de Educação Histórica \& videogames}

- Introdução: a ludificação do passado

1. Discutindo o ensino de História

2. Percurso metodológico e pesquisa-ação

3. Jogos eletrônicos e didática da História

4. Empatia histórica e jogos digitais

5. Proposta de modelo de avaliação da empatia histórica em jogos digitais

- Conclusão - O círculo mágico e o ensino de História

- Referências

- Sobre o autor 


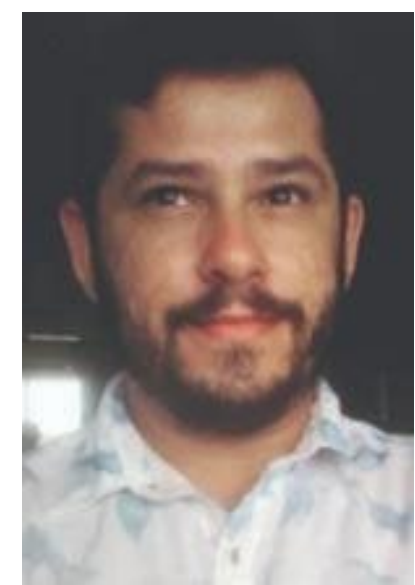

\section{Resenhista}

Fernando de Souza Cruz - Mestre em Ensino de História pela Universidade Federal de Sergipe. É professor da Educação Básica no nível Médio e membro do Grupo de Pesquisas "Ensino de História: Aprendizagem Histórica em espaços escolares e não escolares (UFS)". Publicou, entre outros textos, Diálogos com as memórias da Ditadura Militar: a construção de um jogo para o Ensino de História no nível Médio (2021) e "Diálogos com a memória: uma proposta lúdica no ensino de História para o nível médio em torno de temas relacionados à Cultura autoritária brasileira". Email: fecruzsp@gmail.com.

\section{Para citar esta resenha}

TELLES, Helyom Viana. Educação Histórica \& Videogames. Curitiba: Brazil Publishing, 2020. 200p. Resenha de CRUZ, Fernando de Souza. Aprender com jogos. Crítica Historiográfica. Natal, v.1, n.2, nov./dez. 2021.

\section{Baixar esta resenha em PDF}

(C) - Os autores que publicam em Crítica Historiográfica concordam com a distribuição, remixagem, adaptação e criação a partir dos seus textos, mesmo para fins comerciais, desde que lhe sejam garantidos os devidos créditos pelas criações originais. (CC BYSA) 


\section{Práticas de ensino de História - resenha de "Estágio em} História na Quarentena", de João L. S. Souza, Juliana A. Andrade, Mário E. O. Ramos e Sofia R. C. Vilela

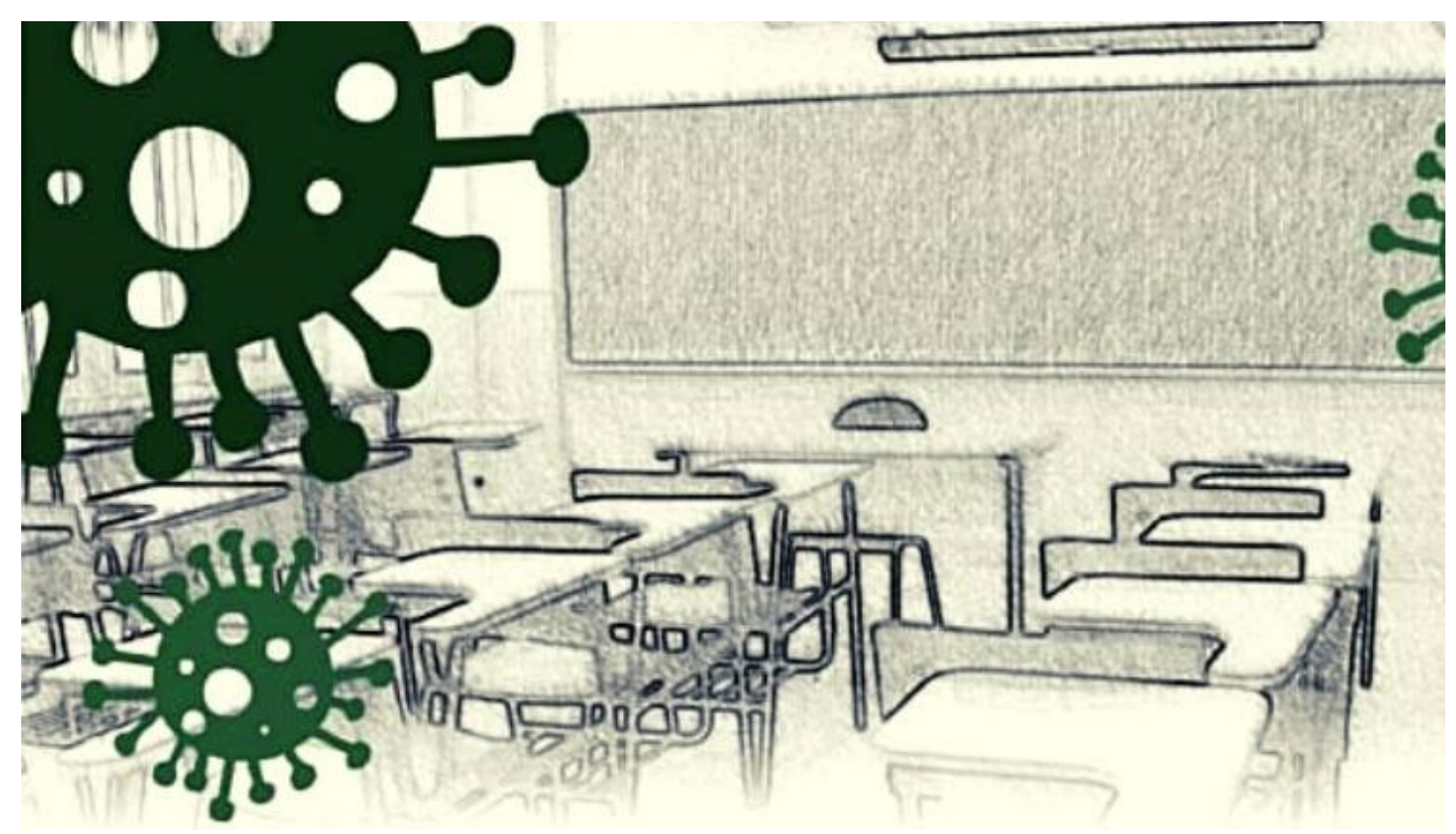

O livro eletrônico intitulado Estágio em História na quarentena foi organizado por João Lucas dos Santos Souza, Juliana Alves de Andrade, Mário Emmanuel de Oliveira Ramos e Sofia Roberta da Costa Vilela, publicado pela Editora Universitária da Universidade Federal Rural de Pernambuco, neste ano de 2021. O texto é fruto das atividades e reflexões da disciplina Estágio Supervisionado para formação de licenciandos na mesma instituição. Conta ainda com a participação de [45] autores, entre professores, formandos em História e cursistas da disciplina de Estágio Supervisionado. Esse grupo viveu, refletiu e escreveu sobre a experiência de atuar em uma das disciplinas dedicadas ao contato com as escolas da Educação Básica e em momento tão especial e específico como o da pandemia da COVID-19. 


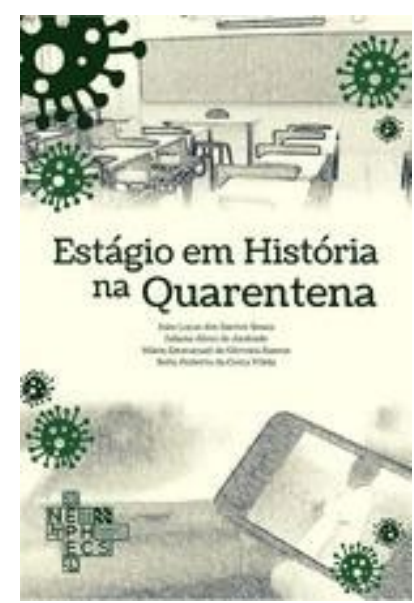

A publicação está dividida em três partes. A primeira agrega textos que condensam entrevistas realizadas com os professores da Educação Básica, atuantes como supervisores dos Estágios. Na segunda parte, são apresentados roteiros para construção de aulas, utilizando tecnologias diversas. Na última parte, os autores discutem temas focados no fenômeno das fake news.

São 71 páginas que valem pelo registro de impasses antigos da formação de professores de História. Valem também como testemunho dos desafios trazidos ou potencializados pelo período pandêmico e que expõem as dificuldades, necessidades e problemas ainda não enfrentados totalmente pela produção do conhecimento histórico acadêmico em relação à cultura escolar.

Como documento do momento vivido por professores e estudantes, tanto do ensino universitário quando dos ensinos fundamental e médio, o livro é um assentamento importante e assim deve ser elogiado pelo esforço. O empenho se demonstra na escrita tarefa pouco enfrentada pelas disciplinas nos cursos de formação de professores -, na dedicação para elaboração de atividades que atendessem aos interesses dos alunos das escolas e os motivassem para aderir às aulas remotas síncronas e as atividades assíncronas. Toda essa diligência faz o leitor ser indulgente quanto aos erros de grafia, digitação e um ou outro equívoco de informação.

Para o domínio do ensino de História é necessário categorizar alguns problemas elencados pela publicação. São problemas que, talvez, possam se transformar em novas reflexões pelos autores e organizadores desta, mas também pelos mais de 40.000 professores de História que atuam no imenso, diverso e contraditório país chamado Brasil.

Em outra ocasião (Oliveira, 2020), apontei o quanto a necessidade das aulas remotas fez os professores universitários se incomodarem com as condições dos seus alunos. Aquilo que defendia como elemento obrigatório no planejamento de ensino - assim ensinamos aos futuros professores - é raramente apropriado pelos professores universitários. Apesar da abundância de dados expostos pelo ENEM e pelas Pró-Reitorias de Graduação das instituições de ensino superior, os professores formadores não empregam esses dados para elaborar seus planejamentos e pensar coletivamente sobre o significado da ascensão à um curso superior ou a escolha por uma licenciatura.

Considerando as várias oportunidades de adentrar com nossas câmeras pelas casas dos nossos alunos ou ao percebermos a recusa sistemática de alguns desses alunos ao modelo imposto pelas necessidades sanitárias é, ao mesmo tempo, estranho que tantos docentes desconheçam as fragilidades econômicas e dificuldades sociais dos discentes. O livro renova a esperança de que esse tema seja incluído de forma sistemática, séria e que possa causar modificações significativas na forma de organização dos cursos de formação de professores.

Nesse sentido, é urgente que enfrentemos esses problemas, como afirmei, categorizando-os, pois, alguns são estruturais da sociedade e outros dizem respeito diretamente aos cursos universitários. Não que os dois tipos não devam ser enfrentados, mas requerem atuações diferenciadas. 
$\mathrm{Na}$ Parte I do livro, onde se processam as entrevistas dos professores-supervisores, aparecem afirmativas que dizem respeito às exigências dos pais para cumprimento de um currículo específico e a BNCC. A imposição da centralidade do professor em sala, devido ao modelo de aula remota, as relações conflituosas das gestões escolares com as novas tecnologias e as dificuldades de adequação de conteúdos ao ensino fundamental são algumas dessas declarações. Sobre cada uma delas, há um mundo de possibilidades de discussões, mas os docentes da Educação Básica mostram-se desprovidos do apoio intelectual e logístico dos colegas formadores de professores no enfrentamento dessas dificuldades no cotidiano escolar.

Para muito além da frase: "na academia a teoria é uma, na escola a prática é diferente", o que publicações desse tipo apontam com veemência é a necessidade de refletirmos nas universidades como problemas que perduram nas escolas podem ser enfrentados na formação de professores. Sem dizer que está tudo errado na escola e dialogando efetivamente com docentes e discentes presentes nas escolas, com todas as suas potencialidades e limites, que problemas poderíamos enfrentar a partir do que foi exposto nesta publicação?

Além do já referenciado, persiste a ideia de que as metodologias de ensino têm a função de facilitar o aprendizado. Em nenhum momento da publicação se referenciam aprendizados de História como o objetivo das atividades (formulação de perguntas, localização espaço-temporal, coleta de informações por meio de vestígios, aprendizados de conceitos, construção de narrativas). Embora estejam presentes - e supomos que também fizessem parte dos objetivos - suas aparições são no sentido de facilitar a aprendizagem, interessar os alunos, transmitir informações.

Apresento tais observações não para dizer que o os autores estão equivocados, mas para pensarmos juntos - em novas experiências e pesquisas - sobre os modos de organização da cultura escolar frente a uma miríade de referências e necessidades. Por essa razão, não nos cabe aproximar dessas realidades para julgá-las, mas compreendê-las e enfrentá-las por meio de novas pesquisas e da proposição de formações alternativas.

No livro, também é notória a excessiva valorização das atividades de ensinoaprendizagem no sentido de contextualizar os fatos estudados e de esses trabalhos e a sua respectiva concentração na exposição dos professores-supervisores ou dos estagiários. Chama bastante a atenção que algo que, em tese, poderia ser desenvolvido por atividades de pesquisa dos alunos e a construção de informações que estão acessíveis nos livros didáticos e na rede mundial de computadores ainda seja majoritariamente apresentado, como um saber do professor. Fica, então, os necessários questionamentos: trata-se da persistência de uma tradição do ensino de História, da formação de professores, das dificuldades de tempo para planejamento de outras atividades, das dificuldades de leitura e/ou acesso à informação dos educandos ou de todas essas causas juntas? Para enfrentar cada uma dessas questões, como podemos atuar na formação de professores?

Ainda há mais três questões expostas por esta publicação que gostaria de elencar. Uma diz respeito às dificuldades de participação das famílias na integração com as atividades escolares. Um docente constata que os grupos de whats app proporcionaram, minimamente, esta integração. Concordamos com a necessidade de envidar esforços para falar a língua da comunidade e acolhê-los. Não é possível nem desejável que não consigamos nos comunicar com as famílias e, com elas, construir ambientes educativos. Imputar todo o problema dessa falta de diálogo ao desinteresse das famílias é replicar 
um modelo de buscar culpados em vez de compreender o que causa o afastamento e tentar sua diminuição.

A segunda questão diz respeito ao fato de uma das atividades referenciar "ciclos econômicos" no Brasil. Não discutirei as críticas à ideia de ciclos ou a persistência dessa categoria em alguns autores acadêmicos, mas o fato de a cultura escolar necessitar combinar anacronismos, análises já criticadas pela academia, senso-comuns e tantos outros elementos para atingir os seus objetivos. Quando a pesquisa acadêmica enfrentará essa realidade e em vez de tratá-la exclusivamente como erro? Quando procuraremos entender os seus meandros?

Por fim, mas de total importância, o tema a que se dedica toda a terceira parte do livro: o fenômeno das fake news e o desafio da sua presença por meio do questionamento dos alunos. O Mestrado Profissional em Ensino de História - PROFHISTÓRIA - produziu muitos trabalhos nesse sentido e a alternativa para combater as notícias falsas, invariavelmente, caminha na direção de uma adequada leitura e interpretação de textos, na aplicação de princípios e procedimentos do método científico e histórico educando para a criticidade. O desafio, contudo, é refletir sobre complicadores dessas soluções, pois, convencionalmente, tratamos desse problema como se fosse uma questão somente de desinformação ou característica das classes subalternas. Penso que essa atitude é uma nova forma de culpabilizar os populares, como infelizmente tem sido o tom dominante das análises sobre a sociedade brasileira.

Os senões apresentados sobre a obra nada mais são que um indício da permanência de problemas formativos, apesar de toda a pesquisa acumulada nos últimos 30 anos, no Brasil. A publicação de uma obra com o sugestivo título de Estágio em História na quarentena ressalta a importância de registros dessa natureza. Por isso deve ser lido, principalmente, pelos professores universitários, já que alerta para o quanto a academia ainda está a dever no atendimento às demandas sociais.

\section{Referências}

OLIVEIRA, Margarida Maria Dias de. Formação dos professores de história os desafios de uma profissão em processo de reinvenção. In: Franck Ribard. (Org.). Os usos políticos do passado: debates contemporâneos. Cidade: Sobral, 2020. p. 213-222. [Link]

\section{Sumário de Estágio em História na quarentena}

- Parte I. Histórias e memórias dos docentes na pandemia

○ Formação e experiência do professor de História na pandemia - Arthur Feller Ricgaud Cardoso e Mateus Santiago de Lima

- Horizontes e travessias no Ensino de História - Ítalo Nery de Albuquerque Rego, Maria Paula da Silva Presbítero e Sofia Roberta da Costa Vilela

- Nas trilhas do ensino remoto - João Cordeiro Neves Júnior, João Lucas dos Santos Souza e Leonardo Júnior do Nascimento

- Os deveres e prazeres de ensinar História - Kayo Victor de Paula, Lucas José do Nascimento e Paulo Andrade Caetano da Silva

- Pandemia, educação e redescoberta - Anderson Bezerra de Jesus, Jonas Clevison Pereira de M. Júnior e Mário Emmanuel de Oliveira RAmos

- Pontes para a educação - Aldo de Souza Ferreira, RAyane Nathaline Dias de Barros 
- Parte II. Como fazer? Aulas de História em tempos de ensino remoto

- Roteiro de vídeo-aula para o campo do Ensino de História - Juliana Alves de Andrade e Mário Emmanuel de Oliveira RAmos

- Colagem audiovisual explicativa sobre a II Guerra Mundial - Ítalo Nery de Albuquerque Rego, Maria Paula da Silva Presbítero e Sofia Roberta da Costa Vilela

- Game Educativo - Kayo Victor de Paula, Lucas José do Nascimento e Paulo Andrade Caetano da Silva

- Panfleto Digital sobre fauna brasileira - Aldo de Souza Ferreira e Rayane Nathaline de Barros

- Telejornal nas aulas de História - João Cordeiro Neves Júnior, João Lucas dos SAntos Souza e Leonardo Júnior do Nascimento

- Vídeo sobre a modernização do Brasil no século XIX - Arthur Feller Rigaud Cardoso e Mateus Santiago de Lima

- Parte III. Fake news como objeto de debate nas aulas de História

- A Ditadura Militar brasileira (1964-1985). Nos tempos de negacionismo e fake news - Daniel Pereira de Souza Filho, Paulo José de Melo Lima, Taylor Uchôa Cavalcanti e Vinícius Cavalcante Melo de Lima

- AS fake news nos anos fiais do Ensino Fundamental - João Paulo Freitas da Silva, José Cordeiro dos santos Neto e Luciana Lima de Andrade Barbosa

- Fake News: vale uma conversa? - Jefferson José BAtista Andrade, Kerolayne Gomes da Fonseca, Lucas Gabriel Gomes da Silva e Maria Tereza de Melo Cavalcanti

Baixar gratuitamente o livro resenhado [Link]

\section{Live de lançamento [Link]}

\section{Sobre a autora desta resenha}

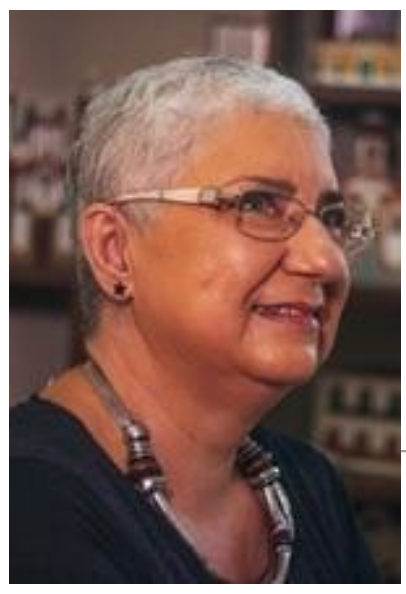

Margarida Maria Dias de Oliveira - Doutora em História pela Universidade Federal de Pernambuco (UFPE), Professora do Departamento e do Programa de Pós-Graduação em História da UFRN. Publicou, entre outros trabalhos, Dicionário do Ensino de História (2020), em coautoria com Marieta e Morais Ferreira, e Formação dos professores de História: os desafios de uma profissão em processo de reinvenção. Email: margaridahistoria@yahoo.com.br

\section{Para citar esta resenha}

SOUZA, João Lucas dos Santos; ANDRADE, Juliana Alves de Andrade; RAMOS, Mário Emmanuel de Oliveira; VILELA, Sofia Roberta da Costa (Org.). Estágio de História na Quarentena. Recife: Editora Universitária da UFRPE, 2021. 69p. Resenha de: OLIVEIRA, Margarida Maria Dias de. Práticas de ensino de História. Crítica Historiográfica, Natal, v.1, n.2, nov./dez. 2021.

\section{Baixar esta resenha em PDF}


(C) - Os autores que publicam em Crítica Historiográfica concordam com a distribuição, remixagem, adaptação e criação a partir dos seus textos, mesmo para fins comerciais, desde que lhe sejam garantidos os devidos créditos pelas criações originais. (CC BY$\mathrm{SA})$ 
Histórias do ensino Superior - resenha de "Da autonomia à resistência democrática: movimento estudantil, ensino superior e a sociedade em Sergipe, 1950-1985", de José Vieira da Cruz

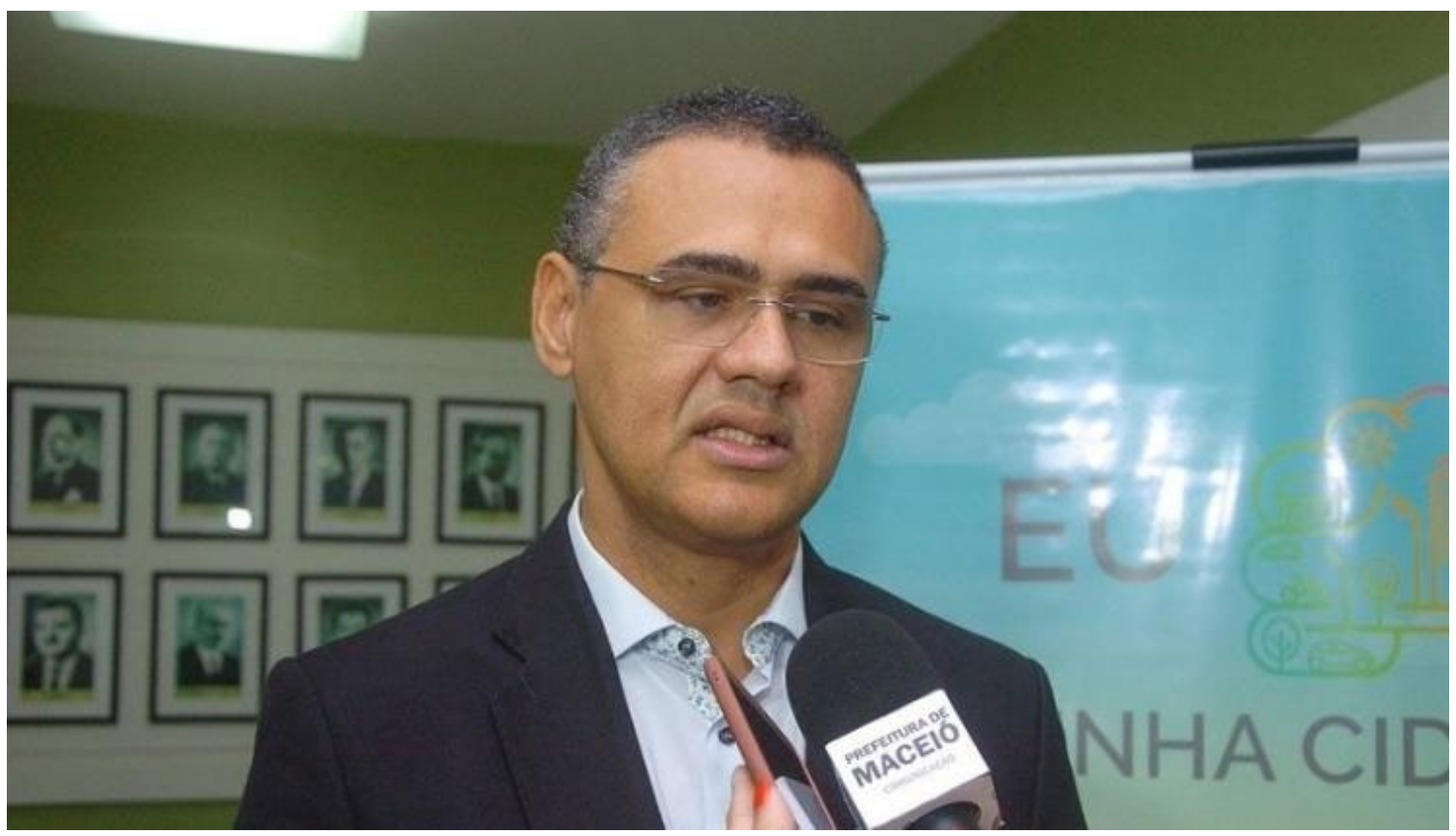

Tribuna do Sertão

Acaba de ser publicada a segunda edição (revista e ampliada) do livro de José Vieira da Cruz, Da Autonomia à Resistência Democrática: Movimento Estudantil, Ensino Superior e a Sociedade em Sergipe (1950-1985). O texto incide sobre o tema da cultura académica, que não está suficientemente estudado e para o qual este livro é um contributo fundamental. 


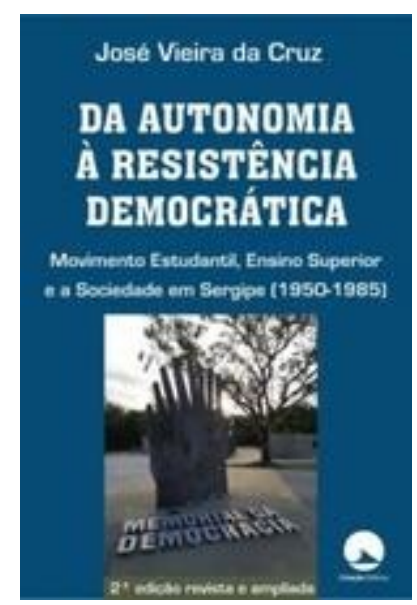

É justamente na década de 1950 que tem início o estudo criterioso e denso que José Vieira da Cruz reedita e ao qual não são alheios nem o elitismo do ensino universitário, nem o alargamento da universidade a novos públicos e novos territórios, nem a relação da universidade com o Estado e com a sociedade; nem a autonomia universitária e o estatuto do estudante. É neste complexo, perfeitamente ajustado ao Brasil em modernização acelerada, que Cruz inscreve e sistematiza o marco teórico; procede a uma revisão crítica da historiografia das universidades; faz a história do movimento estudantil.

Ao caracterizar esta historiografia, o autor isola duas correntes dominantes. Uma inspirada no pensamento nacionalista, cultivado no Instituto Superior de Estudos Brasileiros, e que procurava evidenciar "o papel progressista do movimento estudantil na qualidade de 'forças sociais ascendentes"”, aglutinador de aspectos da cultura nacional com aspectos associados a uma política de esquerda. Esta perspectiva ficou plasmada no livro A Questão da Universidade (1961), escrito pelo Presidente daquele Instituto, Álvaro Vieira Pinto. Uma outra perspectiva historiográfica decorre da análise da acção política dos estudantes, a partir de questões económicas e sociais.

Refere também José Vieira da Cruz que, ainda na década de 60, saiu publicada uma colectânea de textos de "autores clássicos e contemporâneos" sobre a sociologia da juventude, nos quais ressaltam o comprometimento dos jovens com a sociedade global e a promessa de uma nova sociedade. Manifestamente, o autor inclina-se a reconhecer que o inconformismo estudantil pode ser mais do que "um conflito de geração", tal a colocação a que o remeteu Karl Manheim. Se os movimentos estudantis desencadeados em meados do século XX se revestiram de um ideário e de vida própria, ou se são o visível da impossibilidade de aplicar a unidimensionalidade institucional e curricular que caracterizou a modernidade universitária à nova realidade, é um dilema que perpassa o estudo de Cruz, e que deixa o horizonte aberto para aprofundar o estudo sobre maio de 1968. Nessa vaga universal, cuja transversalidade Herbert Marcuse tentou compreender, ficaram silenciadas, face ao radicalismo político e ideológico que abalou a instituição universitária, vozes críticas e reformistas como a de Paul Ricoeur (tanto em Paris, quanto em São Paulo).

O estudo de Cruz é aberto e bem enquadrado. O trabalho de campo e o objecto central recaem no movimento estudantil universitário e no ensino superior em Sergipe. $\mathrm{O}$ autor justifica que o estudo tem início com o surgimento dos primeiros órgãos e periódicos de representação estudantil, cerca de 1950, e termina em 1985, quando, na sequência do golpe e da ditadura civil-militar, os movimentos estudantis se cruzaram com outros interlocutores e outras causas. Entende o autor que a historiografia e a produção académica sobre as universidades têm estado focadas em três planos, que designa de "impasses": a temática de classe que tende a acentuar a dimensão socioeconómica; a centração nos grandes centros: Rio de Janeiro e São Paulo; a relevância atribuída ao período do golpe militar e ao imediatamente subsequente, ou seja entre 1964 e 1968. José Vieira da Cruz propõe-se abordar o tema em Sergipe e tomar a imprensa, os documentos escritos e as fontes orais para inventariar os diferentes tipos de causas e o modo como os estudantes nelas se envolveram. 
Procura também indagar sobre a intelligentsia fora dos grandes ciclos políticos e interpretar utopias, ideias, propostas, dinâmicas que emanam a partir da academia e na relação com as classes dirigentes locais e nacionais.

O livro, como ressalta do título, está dividido em duas partes: Parte I - “Autonomia e participação em tempos de nacionalismos e reformas", e Parte II - "Do ilusório transitório à resistência democrática".

Cada uma corresponde a um ciclo histórico, separados pelo golpe civil- -militar de 1964. Esta cisão assinala um primeiro movimento mais interno às causas, à organização e ao amadurecimento da representação estudantil e do envolvimento estudantil. Foi um tempo de autonomia e institucionalização, de uma cultura e de modos de viver a universidade, fora e dentro de muros. Com os novos cursos e o crescimento da procura por parte de novos públicos sem tradição intelectual e cívica, muitos estudantes viramse desenraizados dos territórios e dos ambientes familiares de origem, boa parte deles habitando residências estudantis, participando de dinâmicas e rituais académicos que contrastavam com a vivência colegial anterior. A presença dos universitários trazia às cidades neo-universitárias dinâmicas socioculturais e rituais novos. O crescimento das Academias forçou à construção dos campi universitários.

Foi um movimento lento e o processo não foi uniforme. Nas novas cidades, como Brasília, veio a gerar cidades outras. O segundo ciclo plasmado no livro corresponde ao interstício do golpe e da ditadura civil-militar e ao tempo subsequente.

São dois ciclos históricos que assinalam que a cultura e os movimentos estudantis incidiram, numa primeira fase, em questões internas e que, numa segunda fase, se mantiveram mais amplos e politizados, como que trazendo os estudantes à realidade e à intervenção cívica, enquanto detentores de uma representação social e política, crítica e prospectiva. Enquanto aquele primeiro ciclo é mais estritamente interno e autonómico, o segundo é de maior endurecimento dos movimentos estudantis perante o poder político, também este mais obstinado em demolir o associativismo estudantil e a politização das universidades.

São ideologias e modos de politização distintos: o primeiro, de identificação e institucionalização, mais alinhado com as questões e as causas intrínsecas aos estudantes e às universidades; o segundo, de resistência e mais alinhado com as questões políticas e socioculturais. Na sequência do estudo, o autor conclui e procura comprovar que, nas décadas de 1950 e 1960, os estudantes de Sergipe se envolveram na criação de uma universidade federal no Estado, ao lado de uma parte

da intelligentsia local, movimento que também mereceu atenção da Igreja Católica e do governo do Estado.

Na primeira parte do livro, composta por 4 capítulos, José Vieira da Cruz adapta uma perspectiva diacrónica - desde o surgimento do movimento estudantil no Sergipe, que associa à publicação do primeiro número do jornal Academus, editado em 1951, pelo Centro Académico Sílvio Romero da Faculdade de Direito de Sergipe, à invasão e destruição de documentação da sede da União Estadual dos Estudantes de Sergipe, na sequência do Golpe Militar de 1964. Este acontecimento interrompeu um movimento de empenho dos estudantes quer na cultura popular quer na criação de uma universidade de Estado. Este último desiderato vinha do VIII Congresso Estadual dos Estudantes Sergipanos, que decorreu na sede da Acção Católica da cidade de Aracaju, em 1958. A Universidade Federal de Sergipe viria a ser inaugurada em 15 de maio de 1968. Por seu turno, fruto do empenho dos estudantes na cultura popular, através do Centro Popular de Cultura, vinha desde o XIII Conclave da União Estadual dos Estudantes de Sergipe, 
realizado na Faculdade Católica de Filosofia de Sergipe, entre 10 e 15 de setembro de 1963.

No capítulo II, o autor refere que o movimento de federalização do ensino superior em Sergipe foi lento, tendo sido notória, nomeadamente nos casos de direito e medicina, a iniciativa civil na fundação e manutenção de faculdades que vieram a ser incorporadas na universidade.

$\mathrm{O}$ acesso ao ensino superior mantinha-se restritivo, em face do total de alunos que concluía o ensino secundário e o vestibular. A principal origem dos estudantes era do Estado de Sergipe, cerca de metade dos quais vinham de outros municípios que não o de Aracaju. Os diplomados ocupavam funções nesses mesmos municípios. Entre 1957 e 1964, 52,5\% dos estudantes eram do sexo masculino. Quanto ao movimento estudantil, o autor informa que, no ano de 1950, foram criados os Directórios Académicos da Faculdade de Ciências Económicas, da Escola Superior de Química, da Faculdade de Direito; em 1951, o Directório Académico da Faculdade Católica de Filosofia; em 1954, o Directório Académico da Faculdade Medicina. Admite que a União dos Estudantes de Sergipe tenha sido organizada entre 1950 e 1951, pois que o Primeiro Congresso de Estudantes de Sergipe decorreu entre os dias 16 e 19 de dezembro de 1951 . Na sequência do II Congresso, em 1953, foi criada a União Estadual dos Estudantes do Sergipe.

Como apresenta o autor, no capítulo III, foi no já referido VIII Congresso de Estudante de Sergipe, em 1958, que os estudantes começaram o mobilizar-se em torno de uma universidade do Sergipe. Nesse mesmo ano, uma delegação da Juventude Universitária Católica visitou o governo do Estado de Sergipe. O envolvimento político dos estudantes ficou manifesto, entre outros movimentos, pelo envolvimento da União Nacional de Estudantes na eleição do Presidente da República João Goulart e, a partir de 1958, na discussão da Reforma Universitária. A tese apresentada pelos Estudantes de Sergipe no I Seminário Nacional da Reforma Universitária, em Salvador, em 1961, incidia sobre exames e currículo; necessidade de um plano de reforma, participação dos estudantes no conselho deliberativo das universidades. No capítulo IV, José Vieira da Cruz sistematiza as principais causas que mobilizavam os estudantes e como foram ficando documentadas na imprensa estudantil e na imprensa periódica. A luta pela representação de um terço proporcional nos conselhos deliberativos das universidades foi generalizada e transversal aos diferentes Estados, e ficou associada à introdução da greve nos modos de contestar universitários. A co-gestão havia-se tornado um movimento internacional. No Congresso dos Estudantes de Sergipe, em 1963, a questão da co-gestão e a da criação de uma universidade, tinham-se sobreposto.

A segunda parte do livro desdobra-se pelos capítulos V a IX. Principia nos movimentos de Março de 1964, que, no Sergipe, envolvem a perseguição aos aliados do Presidente João Goulart e do governador do Estado, João de Seixas Dória. Também atingiram as organizações sindicais, camponesas, estudantis, bem assim como os movimentos culturais e de educação popular, e a Frente de Mobilização Popular. O governador e os líderes estudantis do Sergipe foram presos. A Igreja Católica de Sergipe dividiu-se face aos acontecimentos, tendo os conservadores mobilizado uma marcha de alunos secundaristas, "Marcha com Deus e pela liberdade", que envolveu o Colégio Estadual do Sergipe, de onde saía a principal incorporação de alunos para o ensino superior. $\mathrm{O}$ endurecimento da luta estudantil acentuou-se, nomeadamente em reacção à Lei n ${ }^{0} 4.464$ de 9 de novembro de 1964, Lei Suplicy, que submeteu os órgãos estudantis aos conselhos de instituição e os Directórios Estaduais de Estudantes aos conselhos universitários de cada Estado. Tal endurecimento levou a que o Partido Comunista 
Brasileiro mantivesse a hegemonia do movimento estudantil de Sergipe entre 1966 e 1978.

Como o autor desenvolve no capítulo VI, nos termos da Lei Suplicy, a União Nacional de Estudantes passava a Directório Nacional de Estudantes e ficava subordinada ao Conselho Federal de Educação. O primeiro interventor do Directório Estadual de Estudantes do Sergipe foi nomeado em outubro de 1964 e encetou um processo eleitoral. A direcção eleita fomentou um conjunto de palestras sobre temas regionais.

O movimento de contestação de outros Estados teve repercussão na eleição da nova direcção, em 1966. As eleições ficaram envolvidas em polémica e reacenderam a questão do governo universitário e da universidade de Estado. As circunstâncias alteraram-se com a criação da Fundação Universidade Federal de Sergipe, oficializada pelo Decreto- Lei, no 269/1967. Um dos órgãos extintos foi o Directório Estadual de Estudantes.

No capítulo VII, o autor analisa e documenta a reação à Lei Suplicy, por todo o país e particularmente no Sergipe. Uma das consequências principais foi a perda de influência da Juventude Católica Estudantil, cujas tendências progressistas vieram a incorporar a Acção Popular.

Nas eleições estudantis de 1968, que decorreram já no âmbito da Fundação da Universidade do Sergipe, a principal disputa era entre Acção Popular e Partido Comunista Brasileiro. No Sergipe, estes estudantes contavam com o periódico $A$ Verdade e com acções junto dos estudantes do vestibular, a quem os estudantes de direito ministravam aulas. O ano de 1968, sobretudo a partir dos acontecimentos de Maio, em Paris, rapidamente extensivos a outros locais, foi muito agitado por parte do movimento estudantil de Sergipe. A uma greve dos secundaristas sucedeu um movimento grevista universitário para revisão do funcionamento dos cursos de história e do curso de medicina, nomeadamente conteúdos, exames, sistema de notas, métodos. A agitação acentuou-se com a eleição para o Directório Central dos Estudantes, em 26 de agosto.

A lista da Acção Popular tomou o lema "Libertação" e a lista do Partido Comunista Brasileiro, que venceu as eleições com $60 \%$ dos votos, tomou o lema "Unidade e Acção". Entre as primeiras acções contam-se a luta por uma sede e o envolvimento na causa do potássio, para que fosse explorado por uma empresa mista à semelhança da Petrobras. Notório também foi o envio de uma delegação ao XXX Congresso Nacional do UNE (União Nacional dos Estudantes), que decorreu de modo clandestino em Ibiúna (arredores de São Paulo), tendo vindo a ser dissolvido pelo Exército que prendeu estudantes.

No capítulo IX, o autor documenta as circunstâncias em que foram sendo implementados os Actos Institucionais, designadamente o Acto Institucional n. ${ }^{\circ} 5$. Promulgado em 13 de dezembro de 1968, este Acto suspendia as garantias institucionais por tempo indeterminado. O Directório Central de Estudantes do Sergipe foi encerrado e nos meses seguintes houve estudantes que viram cassados os direitos políticos.

Alguns passaram à clandestinidade. A Portaria do Reitor de 9 de Março de 1969 impediu os estudantes visados de participar da direcção dos órgãos académicos, mas não forçou a expulsão da academia, permitindo- lhes assim a conclusão dos cursos. Esta não-expulsão pode, segundo Cruz, ter acelerado a constituição da Assessoria Especial de Segurança e Informação junto da Universidade do Sergipe. Tendo esta constituição sido contígua ao esvaziamento da sede do Directório Central de Estudantes, conclui que 
entre meados de 1969 e início de 1975, o movimento estudantil em Sergipe, aparece, portanto, eclipsado por uma aparente desarticulação dos estudantes. Em 1975, foi reaberto o Directório Central de Estudantes com representantes dos centros de ensino então existentes - respectivamente associados às áreas de ciências: exactas, humanas, saúde e sociais, que elegeram a direcção de forma indirecta.

Foi, entretanto, organizada, em 1974, no Sergipe, a Ala Jovem do Movimento Democrático Brasileiro, onde também militaram alguns simpatizantes do Partido Comunista Brasileiro. Foi contra os comunistas que, entre 1976 e 1978, foi movida a repressão que ficou conhecida por Operação Cajueiro. A influência destes estudantes havia forçado entretanto a reposição de eleição directas para o Directório Central de Estudantes.

Com efeito, tomando em atenção a Lei n..$^{\circ}$ 5540/1968, que transferira para as universidades a responsabilidade de estabelecer critérios para as estruturas e órgãos estudantis, e atendendo ao Regimento Geral da Universidade, a Resolução n. ${ }^{\circ}$ 10/1978 do CONSU/UFS abria lugar à aceitação da reivindicação dos estudantes para eleições directas para o Directório. Os estudantes eleitos participaram da reconstrução da Unidade Nacional de Estudantes e levaram a cabo uma greve, em Outubro de 1979, na qual conseguiram o fim do jubilamento, que incluía a prescrição de matrícula ao final de alguns anos, e a redução da obrigação de frequência para $40 \%$ das aulas.

Procurando retirar uma conclusão geral sobre a influência do movimento estudantil na sociedade do Sergipe, José Vieira da Cruz, que, no decurso da investigação, deu particular atenção aos indivíduos, nomeando-os, infere que parte dos ex-militantes do movimento estudantil universitário passaram a constituir frações da intelectualidade política, profissional e cultural, sobretudo a partir das duas últimas décadas do século passado. Essas novas lideranças têm participado na administração de Sergipe. Deste modo, pelos ex-universitários tem passado grande parte dos projectos políticos para a sociedade contemporânea.

Projectos que, segundo o autor, foram disputados entre, de um lado, nacionalistas, integrantes dos movimentos populares de cultura e partidos de esquerda, e, por outro lado, liberais, partidos de direita e anticomunistas, replicando assim o binómio que disputou o movimento estudantil.

É dessa dialéctica entre história do tempo próximo e projectos do presente que Cruz dá nota de modo interpelativo, criterioso, muito bem documentado, oferecendo uma narrativa densa e inovadora.

Este livro é um trabalho rigoroso, bem escrito. O tema da cultura académica e dos movimentos estudantis não está suficientemente trabalhado e só estudos como este permitem estabelecer uma racionalidade e um modo de abordagem sob a forma de narrativa interdisciplinar teórica e conceptual, articulada com o mundo da política, particularmente com a política universitária. Ao ler o texto, fazem-se pontes com Portugal, com a historiografia internacional, com a transversalidade do maio de 68 , que, continuando a ser um marco, força a periodização da história universitária.

Esta leitura crítica e integradora da Universidade e do movimento estudantil brasileiros, elaborada por José Vieira da Cruz, referenciado em termos acadêmicos como Cruz, traz o duplo olhar - o interno e o transversal, abrindo para outros temas e outros marcos, em ordem a uma periodização mais geral. Assim pois, em boa hora, o autor decidiu reeditar este livro que constitui um contributo fundamental para a história e a historiografia da 
universidade e dos movimentos estudantis, alma-mater do racional e da inteligência da sociedade contemporânea, como Cruz tão bem documenta e dá a conhecer.

Lisboa, fevereiro de 2021

Sumário de Da autonomia à resistência democrática: Movimento Estudantil, Ensino Superior e a Sociedade em Sergipe, 1950-1985

- Apresentação

- Prefácio à $1^{\mathrm{a}}$ edição

- Prefácio à $2^{\mathrm{a}}$ edição

- Uma História do ativismo estudantil

○ Introdução

- Parte I. Autonomia e participação em tempos de nacionalismos e reformas

- Os caminhos da pesquisa

- O surgimento do movimento estudantil universitário em Sergipe

- Tempos da JUC e da reforma universitária

- A UEES, o IBAD e os movimentos de cultura e educação popular

- Parte II. O ilusório transitório à resistência democrática

- O golpe, a sociedade e o (des)compasso do ME em Sergipe

- A Lei Suplicy, a intervenção na UEES e a DEE de Sergipe

○ "Liberdade sem democracia": a reação dos DAs à Lei Suplicy

- (Re)organização das tendências, os protestos de 1968 e o DCE

- O novo ciclo repressivo, a reabertura do DCE e a luta pelas Diretas

- Considerações finais: a dialética de um passado/presente

○ Referências

- Bibliografia

- Posfácio: a democracia sob outros horizontes....

- Lista de siglas

- Sobre o autor

\section{Baixar gratuitamente o livro resenhado [Link]}

\section{Resenhista}

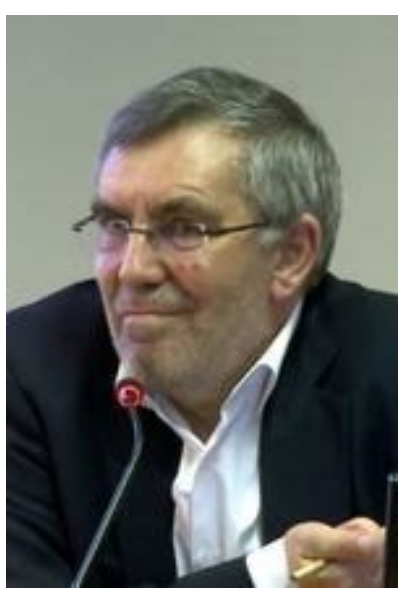

Justino Pereira da Magalhães - Doutor em História da Educação, pela Universidade do Minho, é pesquisador do Instituto de Educação da Universidade de Lisboa e autor de Tecendo Nexos: História das Instituições Educativas (EDUSF, 2004). Email: justinomagalhaes@ie.ulisboa.pt 


\section{Referências desta resenha}

CRUZ, José Vieira. Da autonomia à resistência democrática: Movimento Estudantil, Ensino Superior e a Sociedade em Sergipe, 1950-1985. Aracaju: Criação, 2021. 576p. Resenha de: MAGALHÃES, Justino Pereira da. Histórias do ensino Superior. Crítica Historiográfica. Natal, v.1, n.2, nov./dez. 2021.

\section{Baixar resenha em PDF}

(C) - Os autores que publicam em Crítica Historiográfica concordam com a distribuição, remixagem, adaptação e criação a partir dos seus textos, mesmo para fins comerciais, desde que lhe sejam garantidos os devidos créditos pelas criações originais. (CC BY$\mathrm{SA})$ 


\section{A emergência da História Agrária - resenha de Formação social da miséria no sertão do São Francisco (1820-1920) | Francisco Carlos Teixeira da Silva}

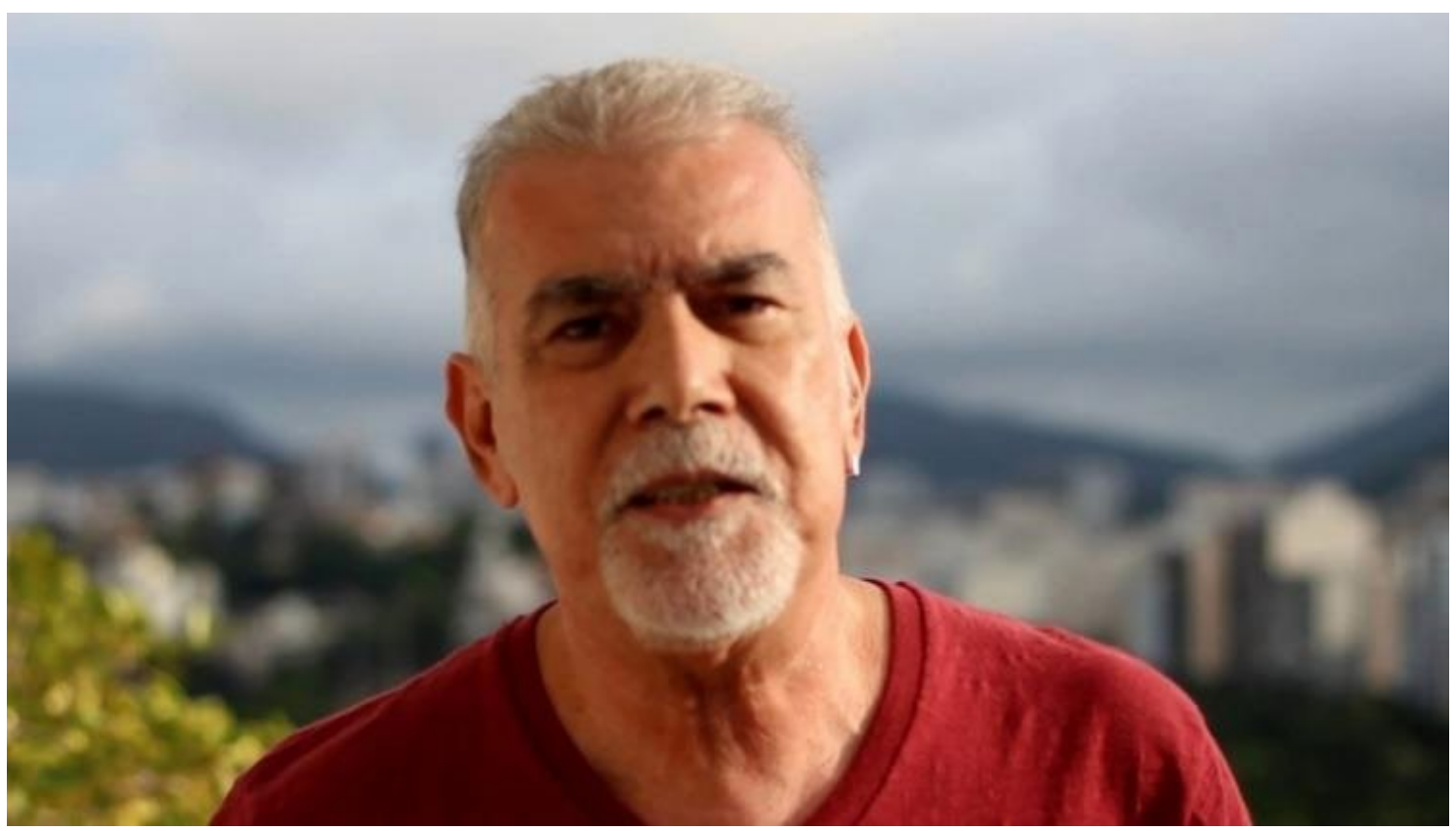

SOS Brasil Soberano - 2017

A publicação Formação social da miséria no sertão do São Francisco (1820-1920), do professor Francisco Carlos Teixeira da Silva (UFRJ) é uma notícia alvissareira para os estudiosos da historiografia sergipana. Chico Carlos, como é carinhosamente conhecido, produziu o texto como dissertação de mestrado, há mais de quatro décadas, sob orientação de Maria Yedda Linhares. Hoje, Chico Carlos é lembrado pelos estudos sobre História Contemporânea e História do Tempo Presente e é provável que alguém estranhe a relação entre o autor e os estudos sobre a história social da agricultura. 


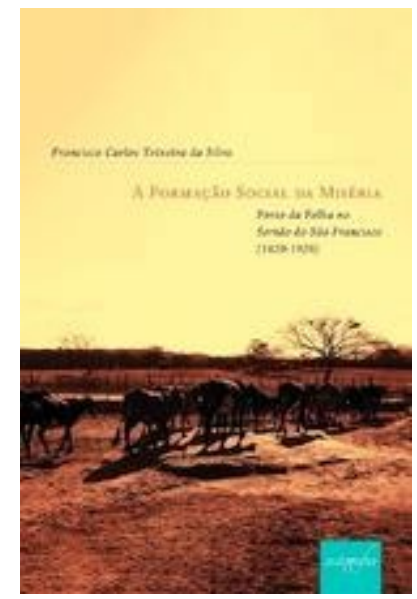

A distância entre a defesa, ocorrida em 1981, e o lançamento desse livro em primeira edição (2018) é reveladora dos avanços da pesquisa histórica em Sergipe com a consolidação dos cursos de pós-graduação na área de história e ciências sociais. Em parte, suas críticas à produção historiográfica da época foram superadas, especialmente no que se refere à abordagem da história social e cultural do Estado. Nesse sentido, o livro é exemplar para o estudante universitário que se debruça sobre a história da historiografia sergipana, pois é tributário da produção brasileira dos anos 1970 e 1980, quando o uso das fontes e a utilização dos métodos da História Agrária contribuíram, significativamente, para a análise da formação do mercado interno e da produção de alimentos no Brasil, com os trabalhos seminais de Maria Yedda Linhares e Ciro Flamarion Cardoso, que retornavam do exílio para o convívio acadêmico nacional.

Como a estrutura de posse e uso da terra é expressão das relações sociais de produção e da estrutura de classes, o livro serve de ponta de lança para refletir os dramáticos conflitos sociais na centúria proposta como periodização, a partir do primeiro censo da Freguesia de São Pedro de Porto da Folha (1820) e o primeiro recenseamento agrícola do Brasil (1920). Esse momento é fundamental para entendermos o processo de "formação social da miséria" no Sertão do São Francisco, com o avanço das fazendas de gado sobre a pequena produção camponesa, sob a liderança da oligarquia pecuarista.

A mudança do uso da "terra de refúgio e trabalho", ocupada por remanescentes dos povos originários, quilombolas e um vigoroso pequeno estrato de pequenos produtores, para a "terra de negócio", das fazendas de gado "à solta" serve para compreender a origem social da miséria na região, com a submissão da pequena propriedade aos interesses pecuaristas. $\mathrm{O}$ conflito entre camponeses e criadores tem como resultado a extinção das terras comunais (heréus, como eram conhecidas), destruindo a "intensa vivência comum entre negros, índios e brancos pobres" pelo fato de que as terras do Morgado de Porto da Folha não poderiam ser compradas ou vendidas, sendo "apossadas em comum pelas diversas famílias camponesas" (p. 76 e 77).

Da precária e diversificada documentação histórica relativa à Sergipe, o historiador demonstrou, de modo cabal, que a história do Sertão "é largamente uma série de expropriações sucessivas das terras dos primeiros posseiros" (p. 130). No caso do Sertão do São Francisco, aos poucos uma poderosa oligarquia de criadores de gado, capitaneada pelas famílias Alves, Feitosa e Britto, açambarcou terras locais de melhor qualidade, como o Aldeamento dos Índios da ilha de São Pedro, entre outras, em um conluio entre os representantes canavieiros do Vale do Cotinguiba e os do Hinterland pecuarista.

Nesse processo de luta pelo uso da terra e das fontes de produção de água com os plantadores de algodão e os criadores de gado, a variedade de cultivos agrícolas cedeu ao sistema de algodão-gado, produzindo uma camada mínima de homens ricos, que representavam a classe dominante sertaneja, controladora da política local. O monopólio da família Britto sobre boa parte das atividades pecuaristas à época representava a "imensa dependência dos grupos dominantes ao monopólio da terra", conseguido "através de mecanismos de coerção e expropriação nitidamente extra econômicos" (p. 94). Esses mecanismos foram decisivos na diminuição absoluta do rebanho suíno, 
central na estratégia de manutenção dos camponeses, com a assunção de ovinos e caprinos como alternativa aos dominados, pois eram mais aptas às novas frentes de expansão em terras mais áridas ou semiáridas de Poço Redondo e Canindé do São Francisco, para onde foram empurrados os camponeses.

Na segunda metade do século XIX, com as epidemias de cólera e da fome, surtos de banditismo emergiram na região, fazendo com que as autoridades expressassem a necessidade do "enquadramento dos pobres", colocados como fonte da morbidez, da agitação e da intranquilidade. Além da necessária ajuda aos pobres e flagelados, "alguns ilustrados de Porto da Folha e de Gararu não hesitaram em dar ao crime e a violência o status de traço de caráter sertanejo" (p. 214). Sem dúvida, essas condições pavimentariam a adesão aos grupos de cangaceiros ou mesmo às tropas volantes, quando da chegada de Lampião à região no final dos anos 1920 e por toda a década de 1930.

A ideia de frentes de trabalho foi uma das opções de enfrentamento da seca no sertão do São Francisco, antecipando ações governamentais que marcariam todo o século XX. No caso de Porto da Folha, a prefeitura contratou 77 trabalhadores que eram pagos com porções de farinha, em 1890 (p. 202). Essas ações, entretanto, não foram suficientes para amainar a fome e os grupos dominantes solicitaram reforços policiais para $\mathrm{o}$ controle da população esfomeada que ameaçava a ordem latifundiária.

Portanto, além da expropriação cotidiana das terras e da construção de corpo legal das autoridades municipais, vinculadas aos criadores de gado, ao camponês restava poucas opções: ou se submetia ao serviço dos grandes proprietários ou, "expulsos como camponeses, voltariam como flagelados, mendigos e ladrões para os quais havia os campos de trabalho e a prisão" (p. 210).

Ao tomar partido de denunciar a miséria nos sertões do São Francisco nos anos 1970, o historiador respondia às questões do tempo presente em que foi escrita a dissertação, quando militantes da Igreja católica desenvolviam importante trabalho de organização dos trabalhadores rurais e de luta pela reconquista das terras indígenas na ilha de São Pedro.

Entretanto, apesar de seu compromisso ético-político, não compreendi a exclusão no formato de livro do capítulo correspondente à morte dos índios, que correspondia ao capítulo VI da segunda parte do trabalho original. Mesmo que alguns dados já estivessem colocados na parte I, capítulo 1 , o processo de extinção dos índios na Câmara municipal de Porto da Folha, em 1887 e 1888, sob o controle do Coronel João Fernandes de Brito, expôs os lucros conseguidos, conforme documento de 1915, por parte dos apropriadores das terras indígenas, como as famílias Britto, Seixas, Fernandes da Silva e Alves de Lima e Silva (p. 181).

Essa opção não oblitera a contribuição do historiador em explicitar que a formação social da miséria nos sertões brasileiros está umbilicalmente ligada à ausência de democratização ao acesso da terra, tão bem sintetizada em outro livro do autor e da professora Maria Yedda Linhares, Terra Prometida: Uma história da questão agrária no Brasil (1999). Por certo, os sertões do São Francisco passaram por recentes e intensas transformações econômicas, sociais e culturais, mas, ao ler esse livro, penso que a "modernização sem mudança" mantém uma das "dívidas sociais" mais persistentes na história brasileira sem perspectiva de solução: a questão agrária. 
Sumário de Formação social da miséria no sertão do São Francisco (1820-1920)

- Agradecimentos (Em 1981)

- Apresentação à edição de 2018

- História Agrária, uma opção metodológica

- A Historiografia Sergipana (Nota historiográfica em 1980)

- Parte I. A terra ou a formação social da miséria

1. Terra de refúgio

2. Terra de trabalho

3. Terra de negócio

- Parte II. Os homens ou dos camponeses e criadores

1. Problemas da demografia no Brasil e em Sergipe

2. De quantos homens se fala ou da "solidão dos nossos campos"

3. A morbidade e a morte no sertão do São Francisco - ou a espantosa morte das crianças

4. Homens livres

5. A escravidão sertaneja

- Parte III. A luta ou a maré da miséria

1. Os modos de existência: tentativa de uma análise sócioprofissional para o sertão do São Francisco

2. A seca

3. A maré da miséria

- Conclusão

- Fontes e bibliografia

- Anexos 


\section{Resenhista}

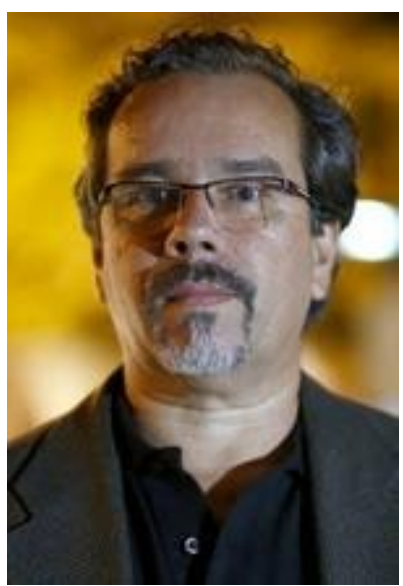

Antônio Fernando de Araújo Sá - Doutor em História pela Universidade de Brasília (UnB), professor do Departamento de História e do Mestrado em História da Universidade Federal de Sergipe e editor da Ponta de Lança - Revista Eletrônica de História, Memória \& Cultura. Publicou, entre outros títulos, Rio Sem História? Leituras sobre o Rio São Francisco (2018) e Entre sertões e representações: ensaios e estudos (2021). E-mail: fernandosa1965@gmail.com.

\section{Para citar esta resenha}

SILVA, Francisco Carlos Teixeira da. Formação Social da Miséria: Porto da Folha no Sertão do São Francisco (1820-1920). Rio de Janeiro: Autografia, 2018. 194p. Resenha de: SÁ, Antonio Fernando de Araújo. A emergência da História Agrária. Crítica Historiográfica. Natal, v.1, n.2, nov./dez. 2021.

\section{Baixar esta resenha em PDF}

(C) - Os autores que publicam em Crítica Historiográfica concordam com a distribuição, remixagem, adaptação e criação a partir dos seus textos, mesmo para fins comerciais, desde que lhe sejam garantidos os devidos créditos pelas criações originais. (CC BY$\mathrm{SA})$ 